\title{
Microbial dynamics in autotrophic and heterotrophic seawater mesocosms. II. Bacterioplankton community structure and hydrolytic enzyme activities
}

\author{
Alison E. Murray ${ }^{1, *}$, Carol Arnosti ${ }^{2}$, Christina L. De La Rocha ${ }^{3}$, \\ Hans-Peter Grossart ${ }^{4}$, Uta Passow ${ }^{3}$ \\ ${ }^{1}$ Division of Earth and Ecosystem Science, Desert Research Institute, 2215 Raggio Parkway, Reno, Nevada 89512, USA \\ ${ }^{2}$ Department of Marine Sciences, University of North Carolina, Chapel Hill, North Carolina 27599-3300, USA \\ ${ }^{3}$ Alfred-Wegner-Institut für Polar- und Meeresforschung, Am Handelshafen 12, 27570 Bremerhaven, Germany \\ ${ }^{4}$ Institute of Freshwater Ecology and Inland Fisheries, Dept. of Limnology of Stratified Lakes, Alte Fischerhütte 2, \\ 16775 Stechlin, Germany
}

\begin{abstract}
A 20 d seawater mesocosm experiment was conducted to study microbial loop and carbon cycling dynamics in 3 experimental systems of different trophic status. Two mesocosms were supplemented with phytoplankton (Phaeocystis in one mesocosm and diatoms in another). This report details the variations in bacterial community composition and in carbon utilization potential investigated via assays measuring the hydrolysis of complex polysaccharides and a simple peptide compound. The first half of the study period was dominated by bacterial growth and large shifts in community composition coinciding with utilization of the organic carbon present at the beginning of the experiment, as shown by hydrolysis of specific polysaccharides and drawdown of labile dissolved organic carbon. During the second half of the experiment, bacterioplankton abundance, composition, and enzymatic activities changed in response to the experimental treatments. Multiple correlation analyses implicated co-variation between rRNA gene DGGE phylotypes (e.g. Alphaproteobacteria, Gammaproteobacteria, and Bacteroidetes) and specific combinations of environmental parameters and carbon resources, indicating phylotypic specialization to the experimental mesocosm conditions. Similarly, hydrolysis of 3 polysaccharides (xylan, chondroitin, and Isochrysis extract) correlated significantly with particular phylotypes, providing evidence of species-specific influences on carbon utilization that varied temporally over the experiment period. Aminopeptidase activity mirrored biomass accumulation, as indicated by positive correlations $(>0.80)$ with most biomass indicators determined. These results illustrate that combined molecular and biochemical analysis of active microbial communities can illuminate linkages between specific organisms and important ecosystem processes such as carbon utilization. Additionally, our findings show that trophic status was reflected in community composition and carbon utilization activities.
\end{abstract}

KEY WORDS: Polysaccharide hydrolysis - Bacterial community composition - Carbon utilization . Leucine hydrolysis $\cdot$ Succession $\cdot$ Mesocosm

\section{INTRODUCTION}

The upper ocean ecosystem provides the 'medium' for vast amounts of inorganic carbon to be fixed by phytoplankton and picophytoplankton ( 45 gigatons of $\mathrm{CO}_{2}$ fixed per year; Falkowski et al. 1998), mostly in the form of organic macromolecules such as proteins, polysaccharides, and lipid complexes. The fate of this carbon is balanced between transport to the deep and utilization in the upper ocean by bacteria, potentially by Archaea, and by heterotrophic grazers. Carbon utilization by marine bacteria is often inferred through deter- 
mining growth by measuring thymidine incorporation into DNA (Fuhrman \& Azam 1982) or protein production rates by measuring leucine incorporation into protein (Kirchman et al. 1985). The bulk of bioreactive dissolved organic carbon (DOC) in the ocean is of high molecular weight (Amon \& Benner 1994), a significant portion of which comprises polysaccharides and to a lesser extent proteins (McCarthy et al. 1996). These macromolecules are enzymatically hydrolyzed to lowmolecular-weight forms for microbial utilization (Warren 1996). Thus, marine bacteria play an important role in the hydrolysis of macromolecules in the oceans, an essential step in secondary production processes.

Molecular biological approaches have demonstrated that marine bacteria are very diverse (Giovannoni \& Rappe 2000), particularly at the population level (Thompson et al. 2004), as revealed by small subunit (SSU) rRNA gene surveys. However, the connection between phylogenetic diversity and ecological function is typically quite tenuous. Knowledge of bacterial functional capabilities has mostly been limited to studies of cultures, which are not necessarily representative of the diversity found in natural marine systems, and studies of in situ biogeochemical transformations. Technological improvements over the past $10 \mathrm{yr}$ are beginning to provide insight into these previously obscured connections. Whole genome sequencing of isolates with important biogeochemical capabilities that are dominant in the ocean (e.g. Silicibacter pomeroyi, Pelagiobacter ubique, and Prochlorococcus sp.), and sequencing of ocean metagenomic systems (e.g. DeLong et al. 2006), in which new capabilities and connections between phylogeny and function are being realized, have been of particular use.

An essential aspect of understanding carbon cycling in marine systems is knowledge of organism-specific metabolic capabilities, as well as ecological interactions with physical, chemical, and biological environmental conditions. For example, little is known about the specific microorganisms responsible for hydrolysis of organic macromolecules. Bacteria typically associated with particulate matter (such as the marine Cytophaga, a class of the Bacteroidetes phylum) are implicated frequently in these processes (Cottrell \& Kirchman 2000). The recently sequenced genome of Polaribacter irgensii supports this hypothesis as a large number of aminopeptidase (9) and glycosidase (4) enzymes have been identified (A. E. Murray unpubl. results). Another recently sequenced organism, Silicibacter pomeroyi, has a high genomic capacity for peptide utilization (4 of the same aminopeptidases identified in $P$. irgensii) compared to high-molecular-weight polysaccharide hydrolytic capabilities (there are no corresponding glycosidases to those identified in $P$. irgensii) (Moran et al. 2004), which may reflect its substrate preference.
Extracellular enzyme activity in marine systems has been assessed using substrate analogs (monosaccharides or amino acids linked to fluorophores) to estimate the potential importance of proteins and polysaccharides to marine bacteria in different ecosystems and environmental settings. Increases in hydrolytic activity in response to phytoplankton blooms have been tied to community composition (Pinhassi \& Hagström 2000) and an increase in the enzyme (i.e. $\beta$-glucosidase) diversity (Arrieta et al. 2004). Studies of microbial enzyme activities using polysaccharides rather than low-molecular-weight substrate proxies (Arnosti 1995) have found that there can be a high degree of variability in the extent to which different polysaccharides are hydrolyzed (Arnosti 2000, Keith \& Arnosti 2001), and that there is substantial variability in the hydrolytic capabilities of bacterioplankton communities on latitudinal gradients (Arnosti et al. 2005a).

As part of a multi-faceted study to investigate the dynamics of autotrophic and heterotrophic seawater mesocosms, the present paper reports on marine bacterial abundance, community structure, and enzymatic activity. We used PCR-DGGE (polymerase chain reaction-denaturing gradient gel electrophoresis) to assess the diversity and shifts of the community structure in these experimental systems, plus a suite of fluorescently labeled polysaccharides, as well as a low-molecular-weight peptide analog to measure enzymatic activity concurrently. Thus, the aim of this study was to determine the extent to which differences in net metabolic status or phytoplankton species composition are reflected in the composition and dynamics of the bacterial community, and the consequences of such differences for enzymatic processing of organic matter.

\section{MATERIALS AND METHODS}

Mesocosm description and sampling. Details of the mesocosm experimental design, set-up, and chemical analyses are described by Passow et al. (2007, this issue). Briefly, three 1000 l polypropylene mesocosms were filled with $\sim 800 \mathrm{l}$ of North Sea water sampled ca. $1 \mathrm{~km}$ off Helgoland island, Germany, at $2 \mathrm{~m}$. Onehalf of the volume in each mesocosm passed through $1.2 \mu \mathrm{m}$ cartridge filters; the other half passed through a $50 \mathrm{kDa}$ Pellicon tangential flow filter system (Millipore). This preliminary filtration aimed to remove the majority of the larger components of the planktonic assemblage (grazers and algae) and to reduce the colloidal carbon in the system. It also reduced the prokaryotic counts to $2.16 \times 10^{4}$ cells ml $^{-1}$ at the start of the experiment and likely the viral particle abundance, which was $2.76 \times 10^{6}$ cells ml ${ }^{-1}$ (A. E. Murray pers. obs.). Equal densities of phytoplankton cultures were 
added to 2 of the mesocosms: 1.51 of a non-axenic Phaeocystis globosa culture was added to the Phaeocystis tank, and 31 each of axenic Chaetoceros decipiens and Thalassiosira pseudonana cultures were added to the Diatom tank along with $15 \mu \mathrm{mol} \mathrm{l}^{-1}$ of silicic acid as sodium metasilicate. There were no other nutrient additions. The third mesocosm received nothing else, and is referred to as the No Addition tank. The experiment proceeded for $20 \mathrm{~d}$, during which each mesocosm was sampled approximately every other day for biological and chemical analyses (for accompanying data see Grossart et al. 2007, this issue, Passow et al. 2007). Data presented reflect the time rounded to the nearest 'whole' day, i.e. Day 3.7 = Day 4 .

Seawater samples fixed with glutaraldehyde $(1 \%$ final concentration) were stained with DAPI, then filtered ( 1 to $5 \mathrm{ml})$ onto black filters $(0.2 \mu \mathrm{m}$ polycarbonate, Poretics; 2 replicates each), and counted immediately on a Zeiss microscope at $1000 \times$ magnification. Notes on morphological diversity and cell size were also taken. In addition, samples for nucleic acid extraction (10 1) were processed by filtration first through an in-line $5.0 \mu \mathrm{m}$ Durapore filter, followed by $0.2 \mu \mathrm{m}$ Supor Sterivex cartridges (Millipore), to which $1.8 \mathrm{ml}$ of lysis buffer (Massana et al. 1997) was added, and then the filters were stored frozen $\left(-80^{\circ} \mathrm{C}\right)$ until extraction.

DNA extraction and PCR-DGGE. Nucleic acids from the free-living fraction (5.0 to $0.2 \mu \mathrm{m}$ ) were extracted with enzymatic lysis (lysozyme and Proteinase K), followed by purification with phenol:chloroform:isoamyl alcohol (described by Massana et al. 1997). DNA was quantified by Pico-Green (Molecular Probes) fluorescence on a fluorometer (Labsystems Fluoroskan Ascent), then stored at $-20^{\circ} \mathrm{C}$ until analyzed. Ribosomal RNA gene fragments were amplified using PCR and primers (GC358F and Bact517R) as described previously (Murray et al. 1998). Briefly, PCR reactions (100 $\mu \mathrm{l}$ each) included (at final concentration): deoxynucleoside triphosphates (0.2 $\mathrm{mM}$ each), $\mathrm{MgCl}_{2}$ (3.5 mM), primers (1.0 $\mu \mathrm{M}$ each), Taq DNA polymerase (0.5 U) (AmplitaqGold, ABI), PCR buffer $(1 \times)$ supplied with the Taq, and ca. $10 \mathrm{ng}$ of template DNA. Samples were amplified (ThermoHybaid PCR Express; 28 cycles) following Murray et al. (1998); reactions were verified by agarose gel electrophoresis, then precipitated in ethanol. The DNA from 2 PCR reactions was pooled, then quantified using the Pico-Green method prior to DGGE. Equal amounts of template, low cycle numbers (Suzuki \& Giovannoni 1996), and pooled PCR reactions were used to reduce biases with PCR amplification.

Bacterial community PCR-DGGE analysis and inherent limitations of the approach have been previously described (Schäfer \& Müyzer 2001). In the present study, purified nucleic acid samples (800 ng each) were separated by electrophoresis using a BioRad DCode DGGE apparatus on $8 \%, 1 \mathrm{~mm}$ polyacrylamide gels with 35 to $60 \%$ denaturing gradient run at $1000 \mathrm{~V} \times \mathrm{h}$ following Murray et al. (1996). Gel alignment challenges were mitigated by running common samples (from Days 4, 12, and 20 from 2 mesocosms) along with all samples (10) for 1 mesocosm in the same gel, resulting in a total of 3 gels. Gels were then stained in SYBR Gold (Molecular Probes) for 15 min, UV-illuminated, and photographed. The 3 digital gel images were then processed independently using GelComparII (Applied Maths) to detect bands, relative band fluorescence intensities, and migration distances; together, these measures facilitated alignment of the gels and band comparisons between gels. An empirical cut-off for band detection was set so that only bands with $\geq 1 \%$ of the total intensity for a given lane were counted.

DNA sequencing. Most DGGE bands with unique migration points were excised (totaling 68), including several with identical melting points in adjacent lanes or different gels, for DNA sequence analysis. DNA was eluted into sterile Milli-Q water following beadbeating for $30 \mathrm{~s}$, and bands were sequenced bidirectionally as described by Martin et al. (2006), except we used the original forward primer minus the GC clamp (Bact358F) and the original reverse primer (Bact517R); amplification conditions were the same as described previously. Sequences were compared to the 'nt' and 'env_nt' nucleotide databases provided by the NCBI using BLAST (April 2006 update; Altschul et al. 1990) run locally. The DGGE band partial SSU rRNA gene sequences have been deposited in GenBank under accession numbers EU004152 to EU004185.

In a number of cases (18 of 33), co-migrating bands (with putatively identical sequences) were sequenced from different samples and mesocosms. In each of these instances, at least 2 sequences were aligned and found to be identical; thus, we chose 1 sequence as the 'type' sequence for that band. There were also several bands in which re-amplification and sequencing of the DNA in the excised DGGE bands did not result in high enough quality sequences to report here (a total of 12 bands for which sequences were not determined); these are most commonly the result of multiple sequences contaminating the PCR or cycle sequencing reactions.

Measurement of polysaccharide hydrolase activities. Polysaccharide hydrolase activities were measured using the method of Arnosti $(1995,2003)$. In brief, well-characterized, soluble fluorescently labeled polysaccharides are added to a sample, and changes in the molecular weight distribution of the polysaccharides with time are measured. By knowing the initial concentration and molecular weight distribution of the added polysaccharide, as well as the incubation time, hydrolysis rates can be calculated (Arnosti 1995). 
Fluorescently labeled substrates were prepared from pullulan, laminarin, xylan, fucoidan, and chondroitin sulfate (all from Sigma or Fluka) using the method of Glabe et al. (1983), as modified by Arnosti (1995, 2003). The Isochrysis extract was isolated from a culture of Isochrysis sp. obtained from Reed Mariculture (Instant AlgaePremium 3600, www.instant-algae.com), as described by Arnosti et al. (2005b). Skeletonema sp.derived DOC was provided by H.-P. Grossart; it was the dialysis product from the medium of a $27 \mathrm{~d}$ culture. The Isochrysis- (16.4 mg) and Skeletonema-derived (12 mg) DOC fractions were dissolved in $2 \mathrm{ml} \mathrm{Milli-Q}$ water each, filtered $(0.45 \mu \mathrm{m}$ pore size), then fluorescently labeled using the method described by Arnosti (2003).

Water samples (1 l) were collected from each mesocosm to monitor enzymatic hydrolysis rates. Mesocosm water was dispensed in $20 \mathrm{ml}$ portions into clean glass vials, and a single fluorescently labeled substrate was dispensed into to each sample vial. The $20 \mathrm{ml}$ samples were then divided to yield two $10 \mathrm{ml}$ samples per substrate. Substrate addition levels represent $35 \mathrm{nmol}$ monosaccharide-equivalent per $10 \mathrm{ml}$ water sample; these levels were increased by a factor of 4 for fucoidan and chondroitin sulfate in Sets 3 and 4 (see below). Addition of a substrate effectively doubled dissolved total carbohydrate concentrations (see Grossart et al. 2007), and therefore should be saturating for the enzymes involved. Samples used to test for activities of free enzymes (enzymes not attached to bacteria/particles; laminarin, xylan, and chondroitin) were filtered through $0.2 \mu \mathrm{m}$ pore size, surfactant-free cellulose acetate filters prior to substrate addition. Killed control samples had $50 \mu \mathrm{l}$ of a $50 \mathrm{mg} \mathrm{HgCl}_{2} / 20 \mathrm{ml}$ Milli-Q solution added 5 min prior to substrate addition. Blank samples, intended to monitor any possible photodegradation of substrate, consisted of $20 \mathrm{ml}$ of $0.2 \mu \mathrm{m}$ filtered Milli-Q water plus substrate. Four sets of vials were incubated during the course of the mesocosm experiment, beginning on the day after phytoplankton addition to the mesocosms (Mesocosm Day 1), and then on Days 5, 9, and 13. Each set of vials was sub-sampled at 48, 96, and $144 \mathrm{~h}$ after substrate addition; Sets 1 to 3 were also sampled $240 \mathrm{~h}$ after substrate addition. The sets were arranged so that sampling times from different sets overlapped, e.g. $240 \mathrm{~h}$ of Set 1 was the same time point as $144 \mathrm{~h}$ of Set 2 and $48 \mathrm{~h}$ of Set 3. Multiple sets were required to monitor enzyme activities throughout the experiment, since substrate hydrolysis was completed (polysaccharides hydrolyzed entirely to monomers) on time scales shorter than the length of the mesocosm experiment. Each vial was sub-sampled by withdrawing at each sampling time approximately $1.6 \mathrm{ml}$ of sample with a disposable syringe and by filtering the samples through $0.2 \mu \mathrm{m}$ pore size filters before freezing in clean glass vials for storage until analysis. The samples for free enzyme activities (which were already filtered through $0.2 \mu \mathrm{m}$ pore size filters) were not pre-filtered prior to freezing.

Samples were analyzed by gel permeation chromatography with fluorescence detection, and enzymatic hydrolysis rates were calculated by monitoring the change in molecular weight distribution of substrate with time, as described in detail by Arnosti $(1995,2003)$. Theoretical turnover times of total dissolved carbohydrates (TCHO) were calculated by dividing TCHO concentrations (Grossart et al. 2007) by the summed enzyme activities for each time point.

Aminopeptidase activity measurements. Following Hoppe et al. (1988), stock solutions of 0.5 and $5 \mathrm{mM}$ leucine-methyl-coumarinylamide-hydrochloride (LeuMCA) were made up in methyl cellosolve (ethylene glycol monomethyl ether) obtained from Fluka and Sigma-Aldrich. Leu-MCA from the stock solutions was added to a series of $20 \mathrm{ml}$ samples from the mesocosms to achieve final Leu-MCA concentrations of 0.1 to $200 \mu \mathrm{M}$. From each vial, $2.5 \mathrm{ml}$ was immediately removed, and, to this, $200 \mu \mathrm{l}$ of $\mathrm{pH} 10$ buffer was added, and the initial fluorescence was read on a spectrofluorometer (excitation and emission wavelengths of 364 and $445 \mathrm{~nm}$, respectively). Final fluorescence was measured on a second aliquot after $3 \mathrm{~h}$ of incubation in the dark. The increase in fluorescence over the incubation was used to calculate the velocity of hydrolysis of the Leu-MCA substrate (in $\mu \mathrm{M}$ Leu$\mathrm{MCA} \mathrm{h}^{-1}$ ). Michaelis-Menten curves were fit through the data using the curve-fitting protocol of SigmaPlot (Version 9.0) to yield the maximum potential hydrolysis rate $\left(V_{\max }\right)$, and the half-saturation constant $\left(K_{\mathrm{m}}\right)$, for each mesocosm at each sampling date. Hydrolysis rates of dissolved combined leucine at each time point were also calculated via the Michaelis-Menton equation, $v=\left(V_{\max } \times S\right) /\left(K_{\mathrm{m}}+S\right)$, where $v$ is the hydrolysis rate at substrate concentration $S$. Turnover times of dissolved combined leucine were obtained by dividing the concentration of dissolved combined leucine at each time point (Grossart et al. 2007) by $v$ for that time point.

Data analysis. The key to community composition analysis is the recognition that all profiling approaches have limits in sensitivity of detection. Estimates for DGGE suggest bands representing $>1$ to $1.5 \%$ of a complex assemblage can be detected (Murray et al. 1996). However, depending on the number of rRNA operons per cell or species, DGGE can be even more sensitive, allowing taxa comprising as little as 0.1 to $0.4 \%$ of the community to be detected (Kan et al. 2006). Presence/ absence of rRNA gene phylotypes from the DGGE analyses were used to calculate Sørenson's index pairwise similarity values $\left(C_{\mathrm{S}}\right.$ i Magurran 
1988, adapted to DGGE analysis by Murray et al. 1996) such that: $C_{\mathrm{S}}=2 j /(a+b)$, where $j$ is the number of sequences found in common to both sites, $a$ is the number of sequences at Site $\mathrm{A}$, and $b$ is the number of sequences at Site B. The presence/absence, relative band intensity, and enzyme hydrolysis data were also used in multidimensional scaling (MDS) analyses (Statistica, v. 6.0, StatSoft; Kruskal 1964) to determine relationships over time in the mesocosms between the community profiles and between the different hydrolytic activities. Scree plots were generated to determine the optimal number of dimensions (Kruskal \& Wish 1978), and a stress evaluation table (Sturrock \& Rocha 2000) was consulted to verify that the stress values observed were not the result of randomly arranged data. Non-metric MDS stress in 2 dimensions with 30 objects (tested here) would have a $1 \%$ chance of being random if the value was $>0.328$. To take further advantage of the information in the DGGE gels, which is not quantitative per se due to issues with PCR amplification, we utilized the relative band intensity data as others have done with DGGE data (Fromin et al. 2002), ARISA (Hewson et al. 2007), and T-RFLP data (i.e. Osborn et al. 2000). The relative band intensity data were clustered in 2 dimensions (between DGGE phylotypes and between the mesocosms over the 10 sampling dates) using the program Cluster based on non-parametric Spearman rank correlations (Eisen et al. 1998). Multiple correlation analysis based on the Pearson correlation coefficient (Statistica, v. 6.0, StatSoft) was conducted with phylotype relative intensity data, the Leu-MCA hydrolysis rates, the polysaccharide hydrolysis rates in comparison to 43 other mesocosm chemical and biological variables (Passow et al. 2007), and DOC constituents (amino acids and carbohydrates; Grossart et al. 2007) to identify putative relationships between organisms, rates, and environmental conditions. A family error rate was used since multiple tests were performed to account for correlations arising by coincidence. Significant results for $\mathrm{p}<$ 0.01 and $p<0.001$ are reported. Significant correlations were validated by visual inspection of the data to ensure that the correlations were attributed to nonspurious data points.

\section{RESULTS}

\section{Experimental setting}

The goal of the present study was to follow carbon utilization patterns and the structure of the free-living bacterial community over the $20 \mathrm{~d}$ experimental period. In the Diatom tank a significant bloom devel-

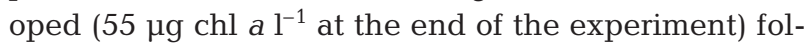

lowing a long lag period, whereas the Phaeocystis tank produced a small bloom (up to $2.1 \mu \mathrm{g} \mathrm{chl} \mathrm{a} \mathrm{l}^{-1}$ ) during Days 10 to 14, which was then likely held under control by grazing (Passow et al. 2007). Since we waited nearly $1 \mathrm{~d}$ for the systems to completely mix, the comparisons are conducted with respect to Day 1 of the experiment. A sample from the No Addition tank at the start of the experiment was collected and analyzed by PCR-DGGE along with the No Addition tank sample on Day 1 (data not shown). The results suggest that there was very little change in the phylotype richness in the first $18 \mathrm{~h}$ of the experiment $\left(C_{\mathrm{S}}=0.94\right)$ in the No Addition tank. In contrast, bacterial communities in both the Phaeocystis and Diatom tanks were between 42 and $45 \%$ different from the No Addition tank at $T_{0}$ by Day 1 of the experiment ( $C_{\mathrm{S}}=0.58$ and 0.55 , respectively).

\section{Bacterioplankton abundance}

In all 3 tanks, bacterial numbers increased rapidly and concurrently from their initially low abundances over the first $4 \mathrm{~d}$ of the experiment, resulting from ultrafiltration of half of the tank water (Fig. 1). This rapid increase in abundance continued until Day 6 in the Diatom tank, while it leveled off after Day 4 in the other 2 mesocosms. In all mesocosms there was a peak in bacterial abundance at Day 6, ranging from ca. $1 \times$ $10^{6} \mathrm{cells} \mathrm{ml}^{-1}$ in the Phaeocystis and No Addition tanks, to $2 \times 10^{6}$ cells ml $^{-1}$ in the Diatom tank. Initially, long cells dominated the bacterial population and by Day 4 , dividing bacteria were observed frequently in all 3 mesocosms. In the Diatom tank, bacteria were observed to colonize senescent-looking diatoms. Whereas bacterial abundances fell after Day 6 in the

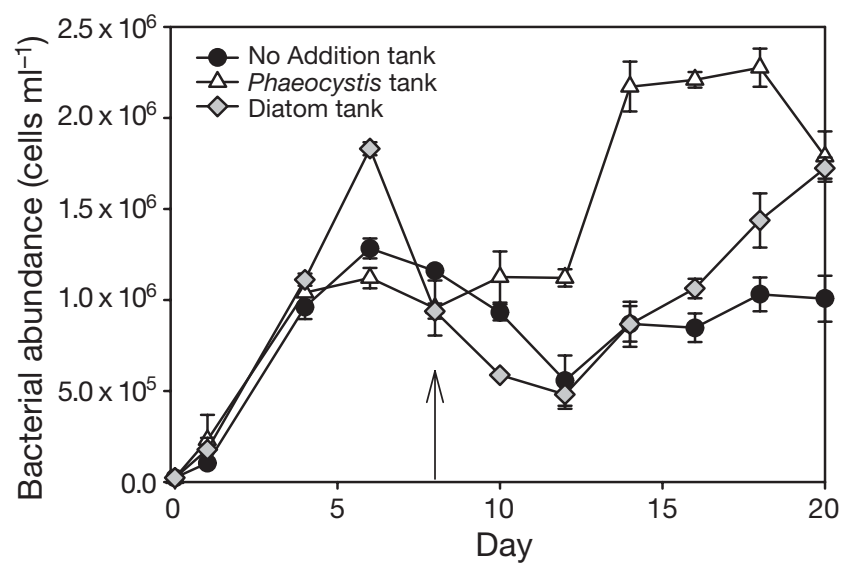

Fig. 1. Bacterioplankton abundance over the course of the mesocosm experiment in the No Addition, Phaeocystis, and Diatom tanks. Arrow marks the time when small bacteria began becoming important, as a result of the increasing grazing pressure 
No Addition and Diatom tanks, they held steady in the Phaeocystis tank through Day 12. During this period the size of bacteria decreased in all 3 mesocosms.

After Day 12 bacterial concentration increased in the Phaeocystis tank and remained higher than in the other 2 mesocosms until Day 18 (Fig. 1). In the Diatom tank a more continuous accumulation of bacteria was observed between Days 12 and 20, whereas the No Addition tank was characterized by only a small increase in bacterial numbers after Day 12. These accumulations of bacteria in all 3 mesocosms were accompanied by a short-lived rise in morphological diversity of bacteria, with numerous large cells by Day 10 in the Diatom tank and by Day 14 in the No Addition and Phaeocystis tanks. Overall, periods of decreasing or constant bacterial numbers were associated with a low morphological diversity and a population dominated by small cells, as is typical for a heavily grazed population (Šimek et al. 1997), whereas more diverse morphotypes of bacteria emerged when bacteria accumulated.

\section{Bacterioplankton composition}

Bacterial DNA (and plastid SSU rRNA genes) readily amplified from the 5 to $0.2 \mu \mathrm{m}$ free-living fraction. Visual inspection of the denaturing gradient gel showed that there were cosmopolitan bands (referred to hereafter as phylotypes), as well as clear shifts in all 3 mesocosms over the experimental period (Fig. 2).
Overall, 55 unique phylotypes (both bacterial and plastid) were detected: 36 in the No Addition tank, 40 in the Phaeocystis tank, and 44 in the Diatom tank. The total number of bands (in a lane or a set of lanes) is referred to as the phylotype richness (Murray et al. 1996). The total phylotype richness declined in each mesocosm from 17-21 to 15-18 phylotypes over the first $6 \mathrm{~d}$ (though richness in the Phaeocystis tank was already recovering after a low on Day 4), while at the same time bacterial numbers increased in each mesocosm (Fig. 1). Subsequently, the phylotype richness increased to between 22 and 23 phylotypes by Day 10 in the No Addition and Diatom tanks, and, simultaneously, the bacterial abundance declined precipitously to $9.3 \times 10^{5}$ and $5.9 \times 10^{5}$ cells ml $^{-1}$, respectively. The trend was weaker in the Phaeocystis tank, with the richness increasing to 18 phylotypes, while bacterial abundance stayed constant through Day 12. The inverse relationship between richness and abundance is not significant over the $20 \mathrm{~d}$ experimental period, though over the first $10 \mathrm{~d}$ the 2 variables were negatively correlated $(r=-0.65, p=0.04$ for the No Addition and Diatom tanks; $r=-0.51, p=0.05$ for all 3 ). It appeared that bacterial cell numbers were under control of grazers in the latter half of the experimental period (Fig. 1); grazer abundance did not correlate with phylotype richness.

Despite differences in mesocosm treatments and dynamics, 7 bacterial phylotypes were present throughout all mesocosms on all dates (those across the horizontal axis; Fig. 3), though some phylotypes were either

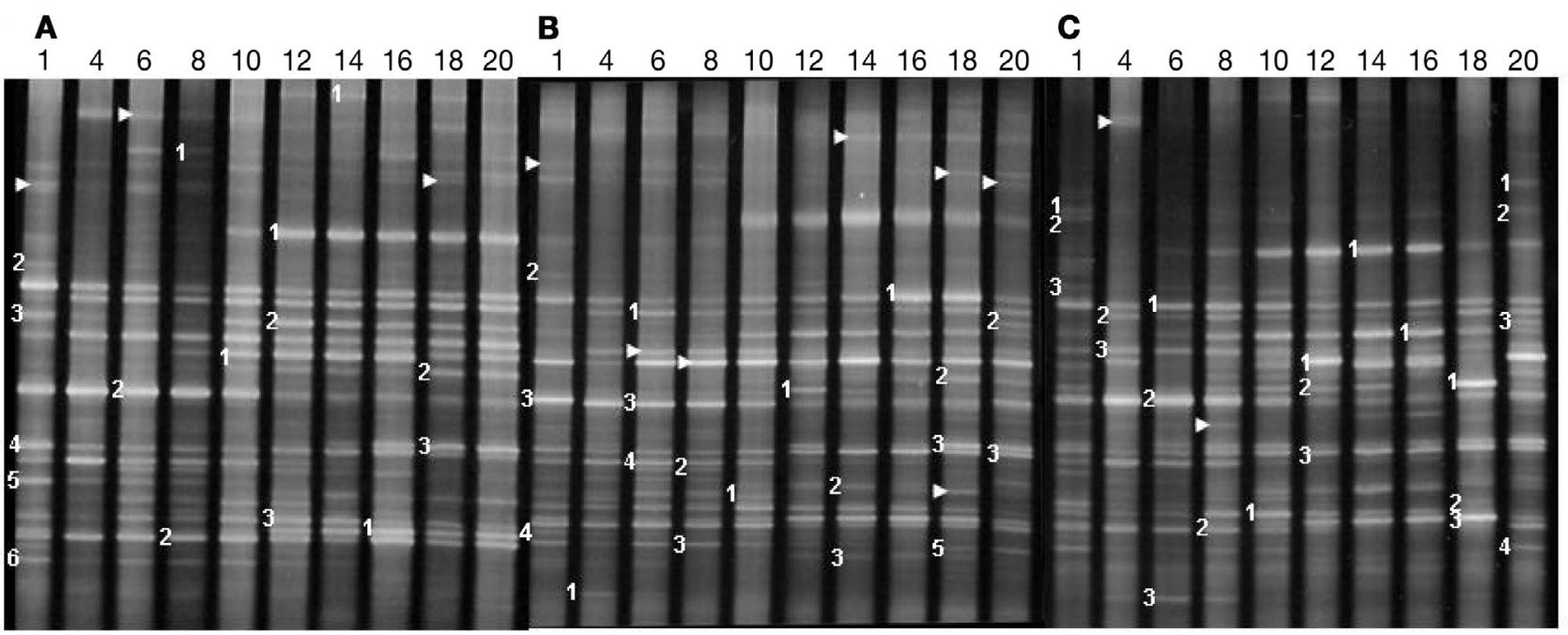

Fig. 2. DGGE profiles of PCR amplified SSU rRNA gene fragments from free-living bacterioplankton during 3 parallel mesocosm experiments sampled over a 20 d period: (A) a No Addition tank, (B) a second tank with a small Phaeocystis globosa bloom, and (C) a third tank dominated by a diatom bloom over the last $6 \mathrm{~d}$ of the experiment. Days sampled are noted above each lane. DNA sequences were obtained for those bands marked with numbers, while arrows point to bands excised that resulted in failed sequencing reactions. This image is a composite of 3 DGGE gels 


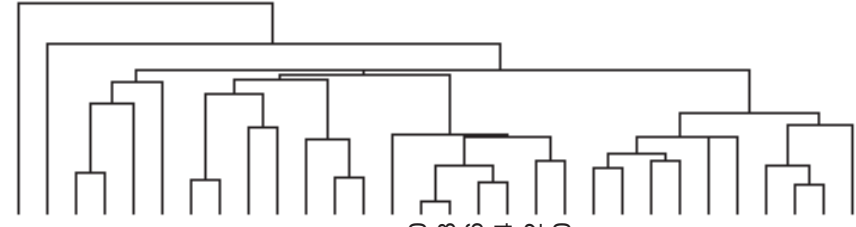

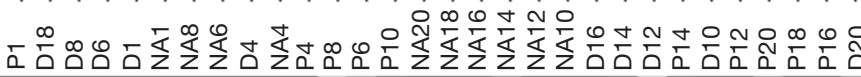

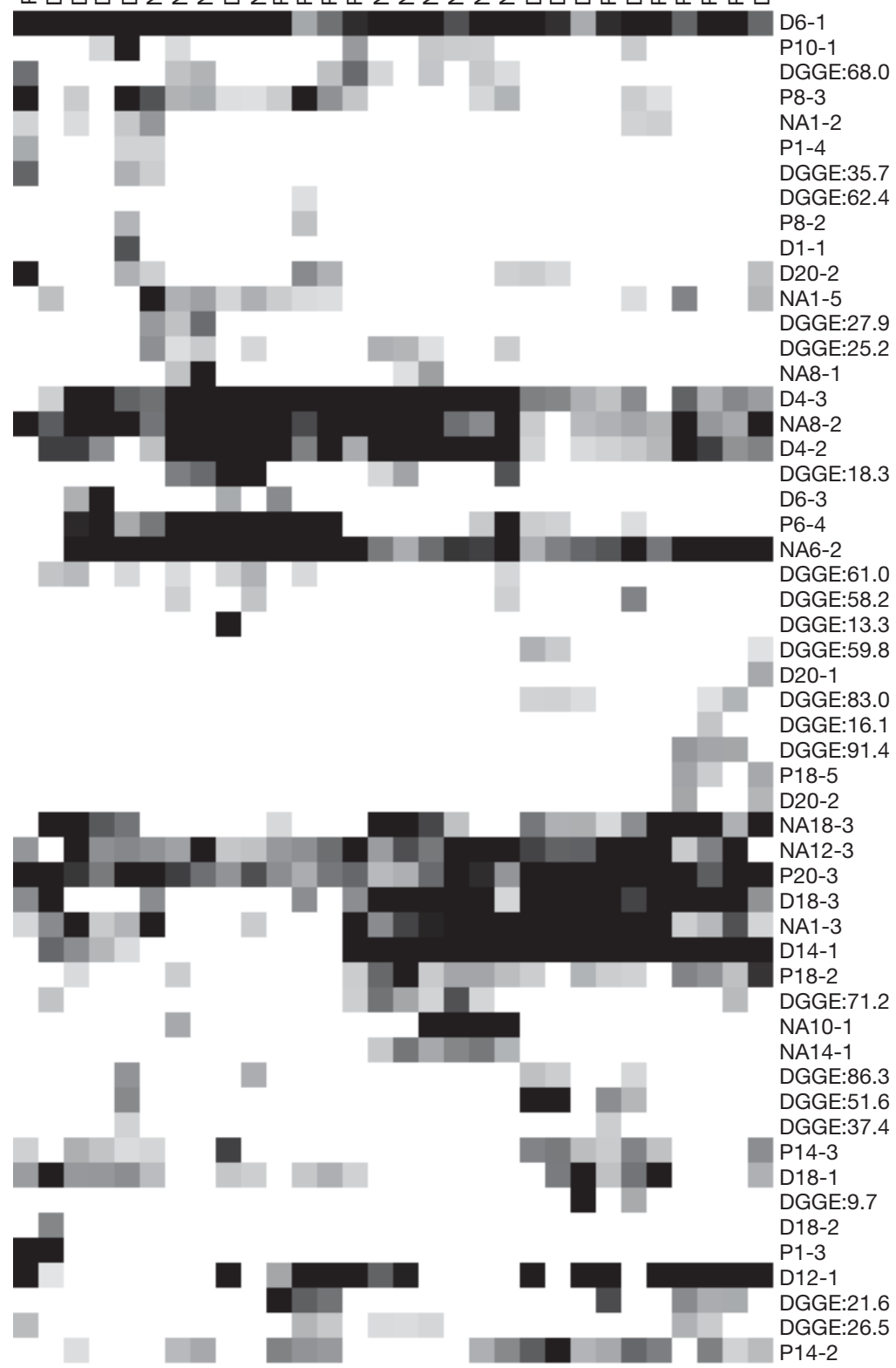

Fig. 3. Two-dimensional clustering analysis (clustering bands and clustering mesocosm samples) based on Spearman rank correlations of relative band intensities was run with the DGGE data that were co-analyzed for 3 denaturing gradient gels. Relative band intensity (low to high) is shown on a white to black gradient. The cluster dendrogram at the top shows the relatedness between mesocosm samples labeled with the tank, followed by sample date. Phylotypes are labeled with relative migration distance in the gel in millimeters, or with an assigned phylotype designation (described in Table 1). The dendrogram showing the relationships between the phylotypes was not shown, though many of the clusters are self-evident based on the relative intensities shown more dominant in the earlier $\left(\mathrm{E}^{*}\right)$ or later $\left(\mathrm{L}^{*}\right)$ parts of the experiment (Table 1). Phylogenetic affiliation of these cosmopolitan sequences was spread among commonly encountered marine bacterial groups, including 3 Gammaproteobacteria (closest relatives were Glaciecola, Colwellia, and OM182 sequences), 2 Bacteroidetes (1 in the Flavobacteriales), a Roseobacter-related Alphaproteobacterium, and a rather distantly related Betaproteobacterium phylotype. NA6-2, the Glaciecola-related phylotype, was the most dominant band in the No Addition and Diatom tanks and the second most dominant band in the Phaeocystis tank, and D6-1, the Flavobacteria-related sequence, was the second or third most abundant phylotype in the 3 tanks.

$C_{\mathrm{S}}$ values comparing the presence/ absence of SSU rRNA gene phylotype profiles for each sample indicate that large shifts occurred over the first $4 \mathrm{~d}$ of the experimental period, particularly in the Phaeocystis and Diatom tanks $\left(C_{\mathrm{S}}\right.$ within each mesocosm Day 1 vs. 4, No Addition $=0.70$, Phaeocystis $=0.38$, Diatom $=0.51$ ). By the end of the experiment, the No Addition (NA) community had continued to shift away from the starting composition such that $C_{\mathrm{S}}$ dropped to a low of 0.51 when Days 1 and 20 were compared. $C_{\mathrm{S}}$ in the other 2 mesocosm communities (P: Phaeocystis; D: Diatom) was more variable, such that $C_{\mathrm{S}}$ ranged between 0.67 and 0.44 for comparisons of Days 1 vs. 12 and 1 vs. 18 for the Phaeocystis tank and from 0.62 to 0.46 for comparisons of Days 1 vs. 10 and 1 vs. 18 for the Diatom tank. Changes were evident by gains and losses of specific phylotypes. For example, several phylotypes (NA1-5, affiliated with the Gammaproteobacteria; and P8-2, affiliated with the Alphaproteobacteria and with P6-4, a Roseobacter-related phylotype with high relative intensity) were present in the first $10 \mathrm{~d}$ of the experiment (Table 1, Fig. 3). Others, such as D18-3 (which was identical over 137 bases to an environmental Sulfitobacter-related clone), D14-1 (a relatively strong phylotype), and NA1-3 (most closely related to oligotrophic isolates from the Oregon coast, OM182 and SAR92 Gammapro- 
Table 1. Phylogenetic affiliation and temporal categories of SSU rRNA gene sequences from excised DGGE bands (phylotypes) in 3 experimental mesocosms varying in trophic status. DGGE phylotypes are named by the tank of origin (NA: No Addition; P: Phaeocystis; D: Diatom) and day sampled (1 to 20 ) followed by the band number in that lane ( 1 to 5 ; refer to Fig. 2 to match up the band numbers). In cases where $>1$ comigrating band was sequenced either from the same gel or a different gel, we selected 1 'type' $\left({ }^{\mathrm{T}}\right)$ sequence to represent each phylotype; these designations are then referenced in the text and other tables. Temporal categories were assigned to those phylotypes with dominant patterns in all (A) tanks; those found predominantly early ( $E_{\text {; }}$ Days 1 to 10 ) or late ( $\mathrm{L}_{\text {; }}$ Days 12 to 20 ) during the experimental period, those dominant within a particular tank and/or only on certain dates are indicated. Asterisks indicate particularly dominant bands with high relative intensities;

D indicates a predominance of the particular phylotype in the Diatom tank

\begin{tabular}{|c|c|c|c|c|}
\hline Phylotype & $\begin{array}{l}\text { GenBank } \\
\text { acc. no. }\end{array}$ & $\begin{array}{c}\text { Temporal } \\
\text { category }\end{array}$ & Group & Relative GenBank \\
\hline P20-3 ${ }^{\mathrm{T}}$, NA1-4 & EU004185 & $\mathrm{A}\left(\mathrm{L}^{*}\right)$ & Bacteroidetes & Uncultured Bacteroidetes bacterium clone 131677; AY922211.1 (93\%) \\
\hline NA6-2 ${ }^{\mathrm{T}}, \mathrm{P} 6-3, \mathrm{D} 6-2$ & EU004155 & A & Gammaproteobacteria & Uncultured Glaciecola sp. clone F4C48; AY794210.1 (100\%) \\
\hline $\mathrm{NA} 8-2^{\mathrm{T}}, \mathrm{D} 8-2$ & EU004157 & $\mathrm{A}\left(\mathrm{E}^{*}\right)$ & Alphaproteobacteria & Uncultured marine bacterium ZD0207; AJ400341.1 (95\%) \\
\hline NA12-3 ${ }^{\mathrm{T}}, \mathrm{D} 10-1$ & EU004159 & $\mathrm{A}\left(\mathrm{L}^{*}\right)$ & Gammaproteobacteria & Marine gammaproteobacterium HTCC2188; AY386344.1 (97 \%) \\
\hline D4-2 ${ }^{\mathrm{T}}, \mathrm{P} 6-1$ & EU004163 & $\mathrm{A}\left(\mathrm{E}^{*}\right)$ & Betaproteobacteria & Uncultured betaproteobacterium clone C319a-R8C-F6; AY678527.1 (94\%) \\
\hline D6-1 ${ }^{\mathrm{T}}, \mathrm{P} 16-1$ & EU004165 & A & Bacteroidetes & Uncultured Flavobacteria bacterium clone SIMO-635; AY712172.1 (100\%) \\
\hline D4-3 & EU004164 & $\mathrm{A}\left(\mathrm{E}^{*}\right)$ & Gammaproteobacteria & Colwellia rossensis strain ANT9271; AY167332.1 (96\%) \\
\hline NA1-5 & EU004154 & E & Gammaproteobacteria & Uncultured marine bacterium COL-25; AY028186.1 (96\%) \\
\hline P8- $3^{\mathrm{T}}, \mathrm{NA} 1-6$ & EU004179 & E & Alphaproteobacteria & Uncultured alphaproteobacterium clone CONW51; AY828396.1 (94\%) \\
\hline P1-4 & EU004176 & E & Alphaproteobacteria & Uncultured marine bacterium D049; AF177568.1 (97\%) \\
\hline P6-4 & EU004177 & E & Alphaproteobacteria & Uncultured alphaproteobacterium clone FFP66; AY828368.1 (97\%) \\
\hline NA1-3 ${ }^{\mathrm{T}}, \mathrm{NA12}-2, \mathrm{D} 16-1$ & EU004153 & $\mathrm{L}$ & Gammaproteobacteria & Marine gammaproteobacterium HTCC2180; AY386343.1 (92\%) \\
\hline D14-1 ${ }^{\mathrm{T}}, \mathrm{NA} 12-1$ & EU004168 & $\mathrm{L}$ & Gammaproteobacteria & Marine gammaproteobacterium HTCC2207; AY386335.1 (95\%) \\
\hline D18-3 ${ }^{\mathrm{T}}$, NA16-1 & EU004171 & L & Alphaproteobacteria & Uncultured Sulfitobacter sp. clone IAFDn44; AY090122.1 (100\%) \\
\hline $\mathrm{P} 18-2^{\mathrm{T}}, \mathrm{NA} 18-2$ & EU004183 & $\mathrm{L}$ & Gammaproteobacteria & Uncultured gammaproteobacterium clone PI_4z10d; AY580739.1 (96\%) \\
\hline NA18-3 ${ }^{\mathrm{T}}, \mathrm{P} 18-3$ & EU004161 & $\mathrm{L}(\mathrm{D})$ & Not available & Uncultured marine eubacterium HstpL37; AF-159638.1 (89\%) \\
\hline NA8-1 & EU004156 & NA & Gammaproteobacteria & Uncultured gammaproteobacterium clone D063; AF367390.1 (92\%) \\
\hline NA10-1 & EU004158 & $\mathrm{NA}^{*}$ & Plastid & Uncultured plastid MoDE-20; AF419370.1 (88\%) \\
\hline NA14-1 & EU004160 & $\mathrm{NA}^{*}$ & Gammaproteobacteria & Uncultured gammaproteobacterium clone PI_4z10d; AY580739.1 (91\%) \\
\hline $\mathrm{D} 6-3^{\mathrm{T}}, \mathrm{P} 4-1$ & EU004166 & P4, D4-8 & Alphaproteobacteria & Marine bacterium SE62; AY038920.1 (96\%) \\
\hline P14-3 & EU004182 & $\mathrm{P} / \mathrm{D}^{*}$ & Alphaproteobacteria & Uncultured alphaproteobacterium clone 131676; AY922210.1 (96\%) \\
\hline D18-1 ${ }^{\mathrm{T}}, \mathrm{P} 12-1, \mathrm{D} 12-2$ & EU004169 & $\mathrm{P} / \mathrm{D}^{*}$ & Plastid & Uncultured plastid MoDE-41; AF419391.1 (97\%) \\
\hline P14-2 & EU004181 & $\mathrm{P} / \mathrm{D}^{*}$ & Gammaproteobacteria & Uncultured gammaproteobacterium clone PI_RT172; AY580758.1 (93\%) \\
\hline $\mathrm{P} 18-5^{\mathrm{T}}, \mathrm{D} 20-4$ & EU004184 & P18-20, D20 & Gammaproteobacteria & Uncultured gammaproteobacterium clone SIMO-1143; AY710583.1 (97\%) \\
\hline $\mathrm{D} 20-3^{\mathrm{T}}, \mathrm{P} 20-2$ & EU004174 & D20, P20 & Gammaproteobacteria & Uncultured marine bacterium COL-31; AY028190.1 (91\%) \\
\hline D1-1 & EU004162 & D1 only & Betaproteobacteria & Uncultured marine bacterium ZD0202; AJ400339.1 (97\%) \\
\hline D12-1 & EU004167 & $\mathrm{P} / \mathrm{D}^{*}$ & Plastid & Uncultured phototrophic eukaryote clone JL-SCS-M59; AY664064.1 (94\%) \\
\hline D18-2 & EU004170 & D18 only & Alphaproteobacteria & Marine bacterium B250-22b; AF076890.1 (97\%) \\
\hline D20-1 & EU004172 & D20 only & Betaproteobacteria & Uncultured betaproteobacterium clone PI_RT99; AY580390.1 (96\%) \\
\hline NA1-2 ${ }^{\mathrm{T}}, \mathrm{P} 1-2, \mathrm{D} 1-3$, & EU004152 & Random & Bacteroidetes & Uncultured Bacteroidetes bacterium clone PI_RT79; AY580614.1 (94\%) \\
\hline P1-3 & EU004175 & Random & Bacteroidetes & Uncultured marine eubacterium OTU_A; AF207850.1 (100\%) \\
\hline P8-2 & EU004178 & Random & Alphaproteobacteria & Uncultured alphaproteobacterium clone CONW51; AY828396.1 (94\%) \\
\hline P10-1 & EU004180 & Random & Gammaproteobacteria & Uncultured bacterium clone ARKDMS-58; AF468261.1 (94\%) \\
\hline $\mathrm{D} 20-2^{\mathrm{T}}, \mathrm{D} 1-2$ & EU004173 & Random & Gammaproteobacteria & Uncultured gammaproteobacterium clone GWS-K5-4; AY515460.1 (90\%) \\
\hline
\end{tabular}

teobacteria groups), and another Gammaproteobacteria sequence (P18-2) were detected mostly during the latter part of the experiment.

A few phylotypes appeared to be specific to the 2 phytoplankton addition mesocosms, including a Sulfitobacter-related phylotype (P14-3) that was present in all Diatom samples, as well as 3 Phaeocystis samples taken during and after the Phaeocystis growth period, and P14-2, a Gammaproteobacteria-related phylotype from Plum Island Sound. A few 'rare' phylotypes were specific to particular experimental mesocosms, including 2 Gammaproteobacteria-related phylotypes (NA81 and NA14-1) that were only present in the No Addition tank and D18-2 and D20-1 (Alpha- and Betaproteobacteria) that were unique to the Diatom tank. There were also a few new phylotypes that only appeared in the last $2 \mathrm{~d}$ of the experiment (D20-3 and P18-5; both were Gammaproteobacteria).

Additional information can be gleaned from the DGGE profiles upon clustering the data (Fig. 3) in the second dimension (comparing the sample profiles) to look for relationships between the samples over the experimental period. The results here suggest that (1) samples taken over the first half of the experiment changed substantially and grouped in some cases according to trophic status of the mesocosm (NA6 and NA8; P4, P6, and P8; D6 and D8 clustered together). (2) The mesocosms separated into 2 different groups during the second half of the experiment - NA in one group and phytoplankton addition in the other. 
Despite very different growth regimes in the Phaeocystis and Diatom tanks, the bacterial community composition appears to have followed a similar pattern of succession. (3) The P1 sample was quite distinct from all others, as was D18 when the richness was low (16 phylotypes). The different composition of the P1 sample, possibly attributable to bacteria added to the non-axenic Phaeocystis globosa culture, became much more similar to the NA and D communities by Day 4 ( $C_{\mathrm{S}}$ between 0.68 and 0.74 , respectively).

Multidimensional scaling (MDS) results (Fig. 4A) show similar patterns to 2-dimensional clustering, though a pattern of temporal succession is more evident; this is most pronounced in the No Addition tank in which a relatively straight line can be drawn from NA1 to NA8, then from NA8 to NA14. The MDS results calculated with both presence/absence and relative phylotype abundance (not shown) demonstrate an overall partitioning between the first $8 \mathrm{~d}$ and the last $10 \mathrm{~d}$ of the experiment. Other than the first 2 time points (NA1 and NA4), the No Addition tank is distinct in comparison to the Phaeocystis and Diatom tanks, which have more points overlapping in 2-dimensional space. The last $4 \mathrm{~d}$ sampled (Days 16 to 20) cluster together for each mesocosm, and are positioned separately from each other, with the Phaeocystis tank at an intermediate point.

\section{Polysaccharide hydrolysis}

The enzymatic hydrolysis measurements for 7 different polysaccharide substrates demonstrate that the bacterial community was actively hydrolyzing substrates at the beginning of the experiment, suggesting that the community was responding to DOC in the North Sea water used in the experiment. Although responses varied among substrates, as well as with time, these variations were very similar among the 3 mesocosms (Fig. 5A-F). Activity patterns in the mesocosms can be divided by substrate into 3 general groups: (1) relatively constant throughout the experiment at intermediate (Skeletonema DOC: 4 to $9 \mathrm{nmol}$ monomer $\mathrm{l}^{-1} \mathrm{~h}^{-1}$ ) or very low (pullulan: 0.5 to $1.5 \mathrm{nmol}$ monomer $\mathrm{l}^{-1} \mathrm{~h}^{-1}$ ) levels; (2) increasing activity throughout the experiment (chondroitin: increasing from ca. 5 to $>10 \mathrm{nmol}$ monomer $\mathrm{l}^{-1} \mathrm{~h}^{-1}$; laminarin: increasing from ca. 2 or 3 to 6 nmol monomer $\mathrm{l}^{-1} \mathrm{~h}^{-1}$ ); and (3) generally decreasing (Isochrysis extract: from ca. 3 to $1 \mathrm{nmol}$ monomer $\mathrm{l}^{-1} \mathrm{~h}^{-1}$ ) or strongly decreasing activity (xylan: from a high near 20 to lows near 1 nmol monomer $\mathrm{l}^{-1} \mathrm{~h}^{-1}$ ) throughout the experiment. Fucoidan was not detectably hydrolyzed at any time point in any of the mesocosms. The killed controls also showed no signs of hydrolysis. The blank samples used to monitor

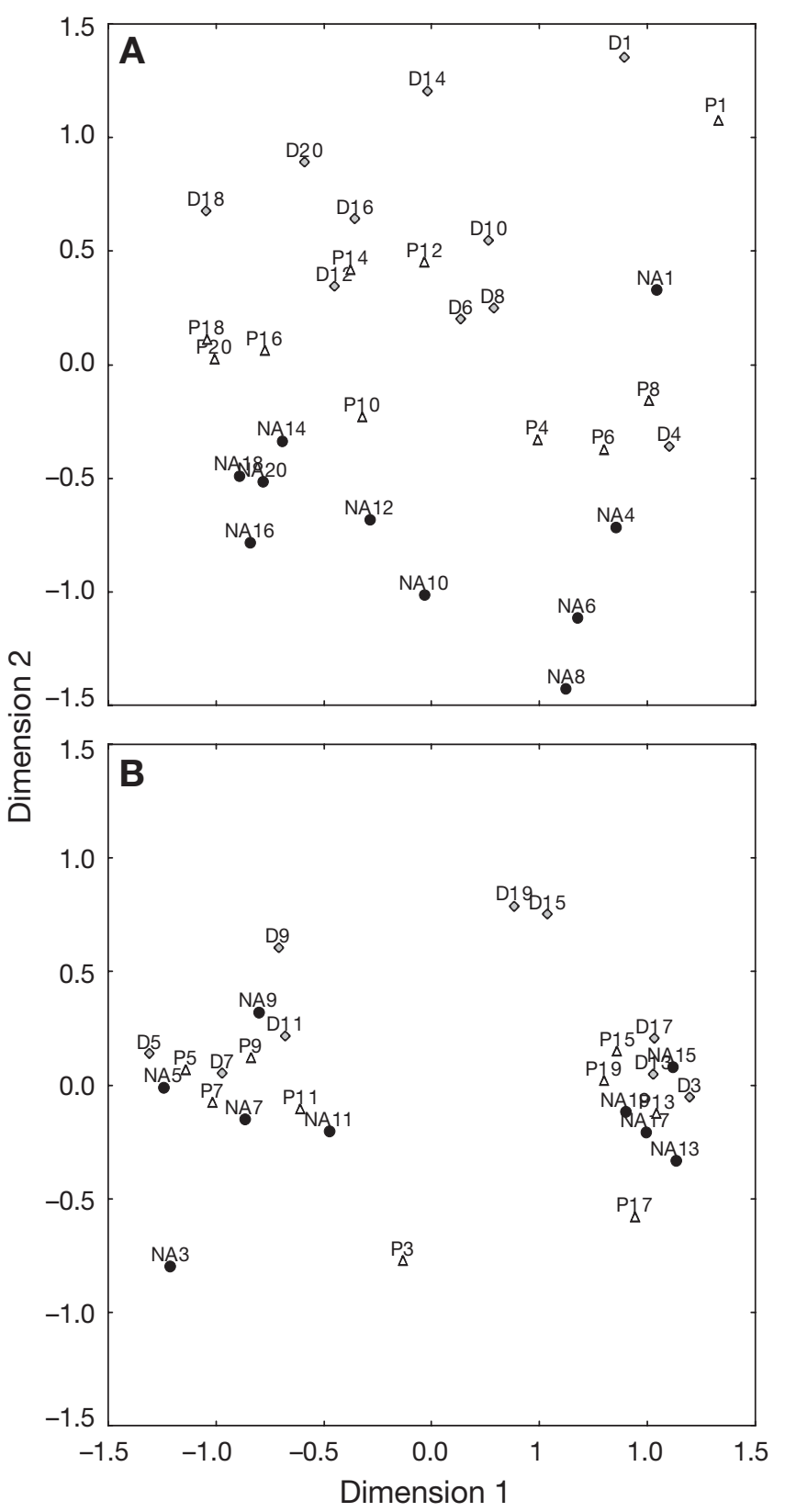

Fig. 4. Multidimensional scaling (MDS) ordinations of mesocosm phylotype profiles and hydrolytic activities. (A) Twodimensional MDS of bacterial communities based on presence/absence of detected phylotypes is shown. Presence/ absence phylotype analyses in 2 and 3 dimensions produced stress values of 0.184 and 0.121 , respectively. Interpretations of the configuration of the 2- and 3-dimensional plots were not different; therefore, the data were represented in a 2dimensional plot. (B) Two-dimensional MDS of polysaccharide hydrolysis rates for 7 substrates and aminopeptidase activities are shown. For the enzyme hydrolysis MDS, the stress values were low at 0.105 and 0.030 , respectively, though, as with the phylotype data, the interpretation of the configuration between the 2 plots was not different, and the data were presented in a 2-dimensional plot. Symbols correspond to No Addition $(\bullet)$, Phaeocystis $(\Delta)$, and Diatom $(\diamond)$ tanks and the date sampled (Days 1 to 20) 

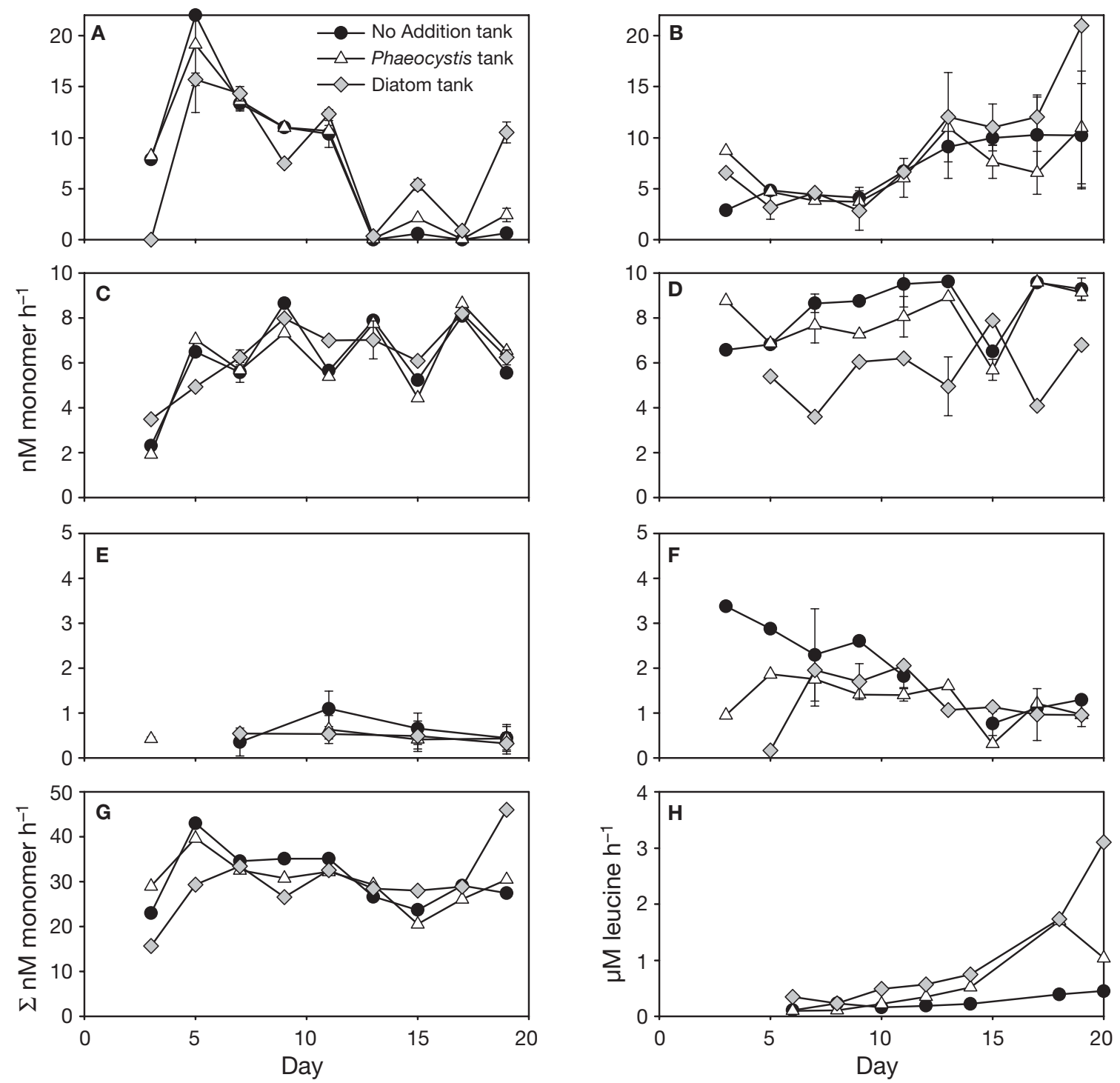

Fig. 5. Potential polysaccharide hydrolysis rates determined for 6 substrates: (A) xylan, (B) chondroitin sulfate, (C) laminarin, (D) Skeletonema extract, (E) pullulan, and (F) Isochrysis extract; the sum of all polysaccharide rates over the 3 mesocosm experiments $(\mathrm{G})$ and leucine hydrolysis $\left(V_{\max }\right)(\mathrm{H})$ are also given. Note changes in scale between the plots. The standard deviation in the potential chondroitin hydrolysis rate (B) for the Diatom tank on Day 20 is off-scale (value of $38 \mathrm{nM} \mathrm{monomer} \mathrm{h}^{-1}$ )

possible photodegradation of substrates showed a reduction in signal intensity over the course of the incubation, likely due to photobleaching of the fluorophore, but there was no indication of substrate hydrolysis. The summed activities of all substrates increased from the first to second time point, and changed relatively little throughout the duration of the experiment (Fig. 5G), in part because declining activities (xylan, Isochrysis extract) were compensated by increasing activities (chondroitin) of specific enzymes; the contributions of the individual activities underlying the summed enzyme activities therefore changed with time.
Hydrolysis rates (described above) were measured for all substrates using unfiltered water, which should include activity of enzymes associated with microbial cell surfaces, as well as enzymes freely released in seawater. Activity patterns were remarkably similar among all 3 mesocosms; lower hydrolysis of the Skeletonema DOC in the Diatom tank was the most notable difference among the mesocosms (Fig. 5). Isochrysis DOC hydrolysis was also higher in the No Addition tank through Day 5, and xylan and chondroitin hydrolysis rates were higher on Day 20 in the Diatom tank.

Although hydrolysis in the bulk water was similar among mesocosms, the extent to which dissolved 
enzymes contributed to hydrolysis differed greatly among substrates, and differed somewhat among mesocosms (Fig. 6). Overall, a high percentage of laminarinase activity could be attributed to dissolved enzymes, while very little of the xylanase activity was measurable in the dissolved fraction in any mesocosm (Fig. 6A). Chondroitin activity (measured only at 4 time points) contributed to a high percentage of total activity in all mesocosms, averaging $36 \%$ of total activity in the Diatom tank, $56 \%$ in the Phaeocystis tank, and $73 \%$ of the No Addition tank. These differences in relative contributions of filtered chondroitin hydrolysis activity among the 3 mesocosms (Fig. 6B) contrast with the similar patterns of total activity (Fig. 5B). Likewise, the extent of laminarinase activity in the filtered fraction differed to a greater extent among the 3 meso-
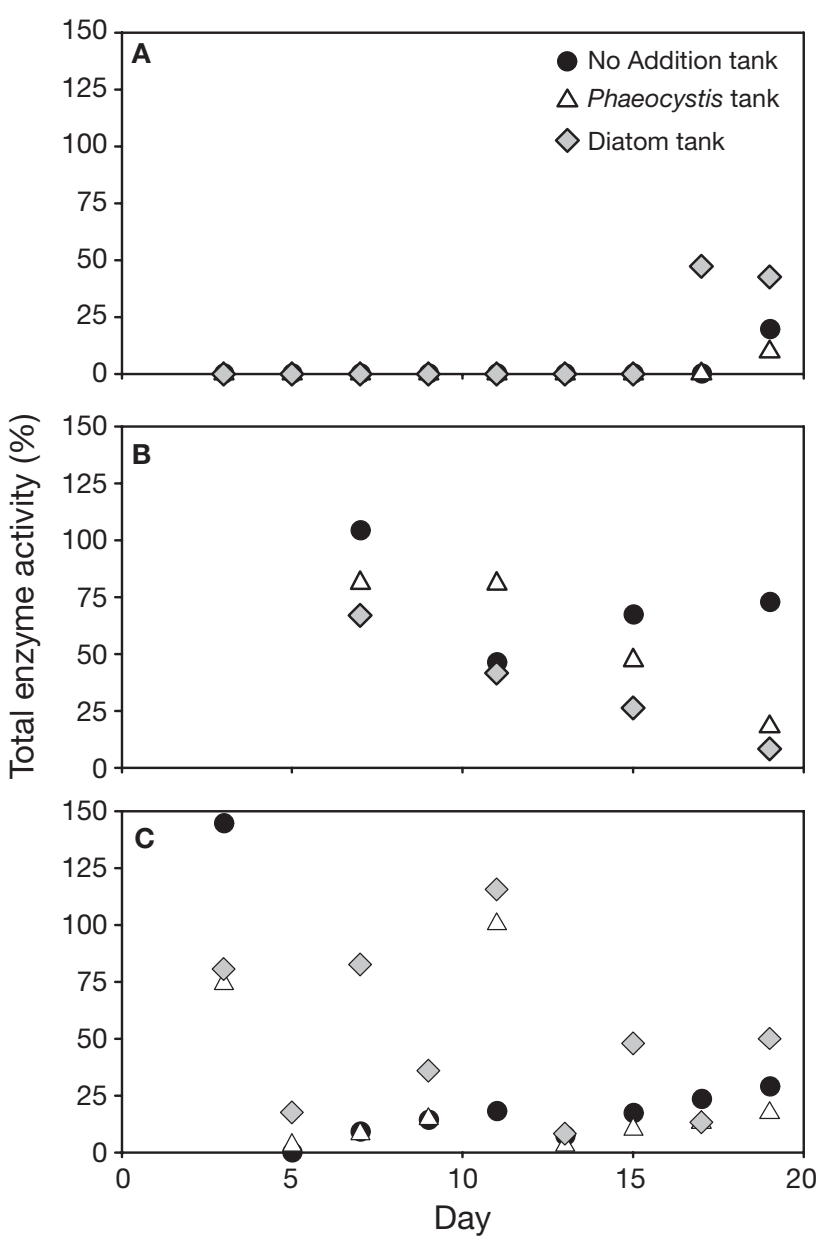

Fig. 6. Relative proportions of dissolved enzyme activities (represented as activity determined in the dissolved fraction $x$ activity determined in the whole water fraction $\times 100$ ) over the $20 \mathrm{~d}$ mesocosm time course. (A) Xylan, (B) chondroitin sulfate, and (C) laminarin: averages of replicates are shown for laminarin data and for chondroitin sulfate data on Day 15; errors for these replicates ranged between 1 and $18 \%$ of the values for all activity determinations $>10 \%$ cosms (Fig. 6C) than did total activity (Fig. 5C). The differences in contribution of dissolved enzymes may relate to 'phase differences' among the microbial communities (see below). Filtered activity was not detectable for xylan, with the exception of the last 2 time points in the Diatom tank, and the last time point for all 3 mesocosms, when total activity was generally low (Figs. 5A \& 6A).

Theoretical turnover times of TCHO were calculated assuming that the total dissolved carbohydrate pool could be hydrolyzed by at least one of the enzyme activities contributing to the summed enzyme activities (Fig. 5G). Initial turnover times of TCHO were on the order of $8 \mathrm{~d}$ for the No Addition and Diatom tanks, and slightly $>4 \mathrm{~d}$ for the Phaeocystis tank (Fig. 7A). Subsequently, in the No Addition and Diatom tanks, there was a rapid decrease in turnover such that by Day 5 the turnover time was 2.8 and $4.1 \mathrm{~d}$ for the 2 mesocosms, respectively. Turnover times varied between 3 and $9 \mathrm{~d}$ over the course of the experiment, with most of the variations (in particular, the longer turnover times of TCHO in the Phaeocystis tank between Days 9 and 15) being driven by changes in TCHO concentration (Grossart et al. 2007), rather than variations in summed

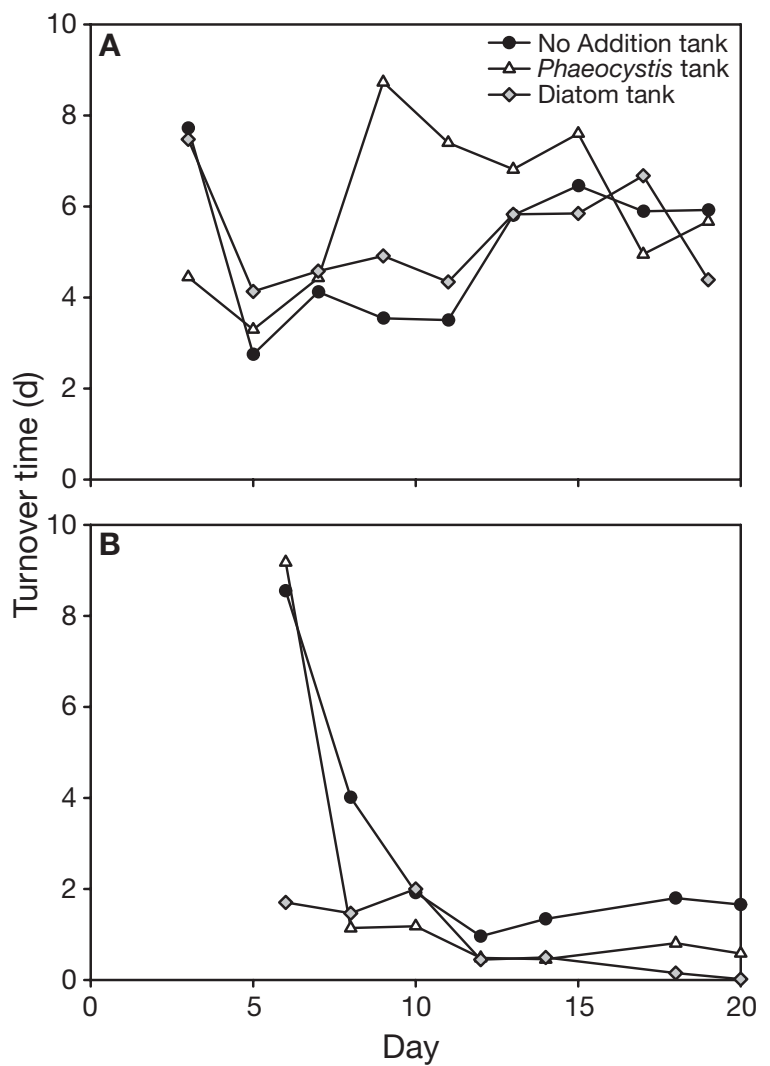

Fig. 7. Theoretical turnover times of total dissolved combined (A) carbohydrates and (B) leucine in the No Addition, Phaeocystis and Diatom tanks. See 'Materials and methods' for calculation methods 
enzymatic hydrolysis rates. Turnover times of TCHO converged close to $6 \mathrm{~d}$ for the No Addition and Phaeocystis tanks and to $4.4 \mathrm{~d}$ for the Diatom tank, on Day 19 of the experiment.

The polysaccharide hydrolysis rates corresponded with individual biological and chemical features. For example, the chondroitin activity coincided with phytoplankton and flagellate growth and associated measured features (Appendix 1, available as Supplementary Material online at www.int-res.com/journals/ suppl/a049p123_app.pdf), the xylan activity was more weakly, but significantly, related to decreases in DFCHO (dissolved free carbohydrates), DFAA (dissolved free amino acids), and DCAA (dissolved combined amino acids) concentrations, and the laminarin activity correlated negatively with DOP and total P. When all enzymatic activities (polysaccharide hydrolysis and aminopeptidase) were considered together and analyzed by MDS, a temporal distinction was apparent, with samples separating into 2 clusters: one including samples through Day 11 and the other commencing with Day 13 (Fig. 4B). Other samples that stood apart from the clustered activities were the activities measured on Day 3 in each mesocosm (the Diatom tank point clustered with the later half of the experiment) and on Days 15 and 19 in the Diatom tank.

\section{Aminopeptidase activity}

Aminopeptidase activity estimated by measuring hydrolysis rates of Leu-MCA at saturating concentrations indicated that $V_{\max }$ were quite similar (0.10 to $0.35 \mathrm{nM} \mathrm{h}^{-1}$ ) among mesocosms from Day 6 (the first day of these measurements) through Day 12, and increased significantly after Day 12 in the Phaeocystis and Diatom tanks (Fig. 5H), reaching nearly equal hydrolysis rates $\left(1.7 \mu \mathrm{M} \mathrm{h}^{-1}\right)$ on Day 18 . The hydrolysis rate in the Diatom tank then almost doubled on Day 20, coinciding with a tripling of the chlorophyll concentration, while the activity in the Phaeocystis tank decreased to $1.0 \mu \mathrm{M} \mathrm{h}^{-1}$. Positive correlations with chlorophyll, oxygen production, POC (particulate organic carbon), PON (particulate organic nitrogen), POP (particulate organic phosphorous), TEP (transparent exopolymer particles), both photoautotrophic and heterotrophic flagellates, and nutrient drawdown (negative correlation with phosphate, silica, total phosphorus) were observed for the Leu-MCA hydrolysis activities (Appendix 1).

Turnover times of dissolved combined leucine (Fig. 7B), calculated from $v$ and dissolved combined leucine concentrations (see 'Materials and methods') decreased markedly between Days 6 and 20 for all 3 mesocosms (Fig. 7B). Turnover times on Day 6 were close to $9 \mathrm{~d}$ for the No Addition and Phaeocystis tanks and $1.7 \mathrm{~d}$ for the Diatom tank. Turnover times dropped rapidly with time for the No Addition and Phaeocystis tanks, and ultimately decreased also for the Diatom tank, reaching values of $1.7,0.58$, and $0.02 \mathrm{~d}$ for the No Addition, Phaeocystis and Diatom tanks, respectively, on Day 20. During this time interval, dissolved combined leucine averaged a relatively constant 5.4 to $5.8 \%$ of total DCAA, and DCAA concentrations increased from ca. 2.3 to $3 \mu \mathrm{mol} \mathrm{l}^{-1}$ on Day 6 to between 4.1 and $4.4 \mu \mathrm{mol} \mathrm{l}^{-1}$ on Day 20 (Grossart et al. 2007). The decrease in dissolved combined leucine turnover time during the course of the mesocosm experiment was therefore driven by increasing rates of hydrolysis, rather than changes in dissolved combined leucine concentrations.

\section{Bacterioplankton, hydrolytic activity, and mesocosm feature correlations}

Relationships between bacterioplankton, hydrolytic activities, and a number of biological and chemical parameters potentially involved in the ecology of these systems were explored with multiple correlation analyses (Table 2). The strongest correlations were found between phylotype signals and dissolved free carbohydrates (DFCHO; sum of the monomers), of which an average $( \pm \mathrm{SD})$ positive correlation between 4 different phylotypes was $0.69 \pm 0.08$. In this case, the strongest correlation, and the highest found in this analysis ( $\mathrm{r}=0.80, \mathrm{p}<0.001)$, was found between P18-2 (a gammaproteobacterium that was present during the later part of the experiment) and DFCHO. There were a number of positive and negative correlations between dissolved inorganic and organic phosphorus. Two phylotypes (P20-3, affiliated with the Bacteroidetes, and D18-3, a Sulfitobacter relative) correlated negatively with nitrate and phosphate, while a betaproteobacterium-related phylotype (D4-2) and a phylotype closely related to a Glacicola environmental clone (NA6-2) were positively correlated with the same nutrients. Two Alphaproteobacteria-related phylotypes (D18-3 and P8-3) had a number of significant correlations with features tested. Of the 5 correlations they had in common (total $\mathrm{P}, \mathrm{DFCHO}, \mathrm{DF}$ [dissolved free]-rhamnose, xylan hydrolysis rate, and heterotrophic nanoflagellates), each was significant in an opposite direction between the 2 phylotypes.

In addition, of particular relevance to this study were the findings that in at least 4 cases positive correlations were found between bacterial phylotypes (NA6-2 and P8-3; NA18-3; and P6-4) and specific polysaccharide hydrolysis rates (xylan HR, chondroitin HR, and Isochrysis extract $\mathrm{HR}$, respectively). The correlation 
Table 2. Multiple correlations between DGGE phylotype band intensity values and mesocosm chemical and biological features. Correlation coefficients $>0.50$ or $<-0.50$ are reported; significant values $(p<0.0001)$ are in bold, for $p<0.01$ specific $p$-values are provided. DOP: dissolved organic phosphorus; POP: particulate organic phosphorus; TOTALP: total phosphorus; PON: particulate organic nitrogen; POC: particulate organic carbon; DOC: dissolved organic carbon; MCHO: total monosaccharides; DFCHO: dissolved free carbohydrates; PCCHO: particulate combined carbohydrates; PCAA: particulate combined amino acids; DC: dissolved combined; DF: dissolved free; PC: particulate combined; HR: hydrolysis rate; HNAN: heterotrophic nanoflagellate abundance, size 1 to $5 \mu \mathrm{m}$; PNAN: phototrophic nanoflagellate abundance, sizes 1 to 5 or 6 to $10 \mu \mathrm{m}$

\begin{tabular}{|c|c|c|c|c|c|c|c|c|c|c|c|c|c|c|}
\hline Measured feature & P20-3 & D4-2 & NA8-2 & NA6-2 & D18-3 & D4-3 & NA18-3 & P6-4 & D18-1 & NA12-3 & D6-1 & D14-1 & P8-3 & P18-2 \\
\hline $\mathrm{NO}_{3}^{-}$ & $\begin{array}{c}-0.64 \\
(0.001)\end{array}$ & $\begin{array}{c}0.51 \\
(0.009)\end{array}$ & $\begin{array}{c}0.59 \\
(0.002)\end{array}$ & $\begin{array}{c}0.55 \\
(0.005)\end{array}$ & $\begin{array}{c}-0.62 \\
(0.001)\end{array}$ & & & & & & & & & \\
\hline $\mathrm{NO}_{2}^{-}$ & $\begin{array}{c}-0.53 \\
(0.007)\end{array}$ & & & & & & & & & & & & & \\
\hline $\mathrm{PO}_{4}$ & $\begin{array}{c}-0.57 \\
(0.003)\end{array}$ & $\begin{array}{c}0.59 \\
(0.002)\end{array}$ & 0.77 & $\begin{array}{c}0.52 \\
(0.007)\end{array}$ & -0.68 & 0.65 & & & & & & & & \\
\hline DOP & & & & $\begin{array}{c}0.60 \\
(0.002)\end{array}$ & $\begin{array}{c}-0.58 \\
(0.003)\end{array}$ & & $\begin{array}{c}-0.63 \\
(0.001)\end{array}$ & $0.70^{*}$ & & & & & & \\
\hline POP & & & & & & & & & 0.74 & $\begin{array}{c}-0.55 \\
(0.006)\end{array}$ & & & & \\
\hline TOTALP & & & & & $\begin{array}{c}-0.62 \\
(0.001)\end{array}$ & & $\begin{array}{c}-0.55 \\
(0.003)\end{array}$ & $\begin{array}{c}0.56 \\
(0.002)\end{array}$ & & & $\begin{array}{c}0.51 \\
(0.006)\end{array}$ & $\begin{array}{c}-0.54 \\
(0.004)\end{array}$ & 0.71 & \\
\hline PON & & & & & & $\begin{array}{c}-0.55 \\
(0.003)\end{array}$ & & & $\begin{array}{c}0.53 \\
(0.004)\end{array}$ & & & & & \\
\hline POC & & & & & & $\begin{array}{c}-0.53 \\
(0.005)\end{array}$ & & & $\begin{array}{c}0.51 \\
(0.007)\end{array}$ & & & & & \\
\hline DOC & & & & & & & & & & & & -0.67 & 0.65 & \\
\hline $\mathrm{MCHO}$ & & & & & & & & & & & & $\begin{array}{c}0.50 \\
(0.005)\end{array}$ & & \\
\hline $\mathrm{DFCHO}$ & & & & $\begin{array}{l}-0.55 \\
(0.002)\end{array}$ & 0.68 & & 0.69 & -0.66 & & & & 0.60 & -0.70 & 0.80 \\
\hline $\mathrm{PCCHO}$ & & -0.60 & & & & $\begin{array}{c}-0.50 \\
(0.005)\end{array}$ & & & & & & & & \\
\hline PCAA & & & & & & & & & & $\begin{array}{l}-0.50 \\
(0.007)\end{array}$ & & & & \\
\hline DC-fucose & & & & & & & & 0.65 & & & & -0.57 & & \\
\hline DF-rhamnose & & & & & 0.63 & & & & & & & & -0.64 & \\
\hline DF-glucose & & & & & & & & & & & & & & 0.69 \\
\hline PC-glucose & & & & & & & & & 0.63 & & & & & \\
\hline DC- $\gamma$-aminobutyric & acid & & & & & & 0.61 & & & & & & & \\
\hline DF-Gln & & & -0.57 & & & & & & & & & & & \\
\hline Xylan HR & & & -0.66 & $\begin{array}{c}0.57 \\
(0.002)\end{array}$ & -0.66 & & & & & & & & 0.67 & \\
\hline Chondroitin HR & & & & $\begin{array}{c}-0.52 \\
(0.006)\end{array}$ & & & $\begin{array}{c}0.59 \\
(0.001)\end{array}$ & $\begin{array}{c}-0.53 \\
(0.005)\end{array}$ & & & & & $\begin{array}{c}-0.57 \\
(0.002)\end{array}$ & \\
\hline Isochrysis HR & & & & & $\begin{array}{c}-0.51 \\
(0.008)\end{array}$ & & & $\begin{array}{c}0.53 \\
(0.005)\end{array}$ & & & & & & \\
\hline Laminarin HR & & & & $\begin{array}{l}-0.56 \\
(0.003)\end{array}$ & & & & $\begin{array}{c}-0.59 \\
(0.001)\end{array}$ & & & & & & \\
\hline \multicolumn{4}{|c|}{ Aminoeptidase activity } & & & & $\begin{array}{c}0.65 \\
(0.002)\end{array}$ & & & $\begin{array}{c}-0.63 \\
(0.002)\end{array}$ & & & & \\
\hline \multicolumn{4}{|l|}{ Bacterial abundance } & & & & & & & & & & $\begin{array}{c}-0.57 \\
(0.001)\end{array}$ & \\
\hline HNAN 1-5 & & & & & $\begin{array}{c}0.53 \\
(0.003)\end{array}$ & $\begin{array}{c}-0.50 \\
(0.005)\end{array}$ & & $\begin{array}{c}-0.57 \\
(0.001)\end{array}$ & & & & & $\begin{array}{l}-0.60 \\
(0.001)\end{array}$ & \\
\hline PNAN 1-5 & & & & & & & $\begin{array}{c}0.56 \\
(0.001)\end{array}$ & & & & & & & \\
\hline PNAN 6-10 & & & & & & $\begin{array}{c}-0.53 \\
(0.003)\end{array}$ & & & & & & & & \\
\hline
\end{tabular}


between P8-3 (an alphaproteobacterium) and xylan hydrolysis $(\mathrm{r}=0.67, \mathrm{p}<0.001)$ was the most significant. A significant correlation between NA18-3 (an unidentified phylotype, only $89 \%$ related to nearest relative) and aminopeptidase activity was also found ( $\mathrm{r}=0.65$, $\mathrm{p}=0.002$ ). This phylotype also correlated strongly with DFCHO, DC- $\gamma$-aminobutyric acid, chondroitin hydrolysis, and small phototrophic nanoflagellates.

\section{DISCUSSION}

This study investigated the bacterial community and related activities over a $20 \mathrm{~d}$ mesocosm experiment in seawater collected from the North Sea. Over the course of the experiment a significant diatomdominated bloom developed in the Diatom tank, and a much smaller Phaeocystis globosa bloom developed in the Phaeocystis tank (Passow et al. 2007). Initial increases in bacterial abundance were more variable between tanks following Day 6. Grazers likely influenced microbial (prokaryotic and eukaryotic) growth, morphological diversity, and cell size in each system, although the effect was most significant for the Phaeocystis tank (Passow et al. 2007). Viruses, which are known to play significant roles in controlling bacterial growth (reviewed by Wommack \& Colwell 2000), may also have affected bacterioplankton growth, although the ratio of virus-like particles to bacteria decreased in all mesocosms (by a factor of 10 in the No Addition tank, by a factor of 4 in the Phaeocystis and Diatom tanks) as the experiment progressed (A. E. Murray unpubl. data). The findings of this study can be crystallized into 5 points: (1) rapid increases in bacterial growth in all tanks over the first $6 \mathrm{~d}$ were followed by different controlled growth patterns in each mesocosm. Growth was likely mediated by grazer and, potentially, by viral control. (2) Over the period studied, phytoplankton species composition (Phaeocystis vs. diatoms) influenced the bacterial assemblage composition more than the hydrolytic potential, with changes most evident during the last few days of the experiment. (3) The most obvious differences over the experiment were shifts in phylotype composition and high-molecular-weight carbon utilization midway through the study; these changes were coincident with increases in heterotrophic grazer abundance in all 3 mesocosms. (4) Microbial community composition influenced hydrolytic capabilities; specific activities can, at times, be attributed to particular community constituents. (5) Hydrolysis patterns of different polysaccharides evolved in distinct patterns with time, suggesting that enzymes with high specificity for substrate structural features were produced by the bacterial and potentially archaeal community.

\section{Relationships between bacterioplankton community, activity, and mesocosm trophic status}

Phylotype richness and MDS (based on band presence/absence) indicated that the Phaeocystis tank was intermediate in overall bacterial richness and phylotype composition at the end of the experiment compared to the other 2 mesocosms. This position potentially reflects the differing trophic status of the experiments determined by oxygen production and respiration determinations (NA: heterotrophic, P: balanced system, and D: autotrophic; Grossart et al. 2007) and the partitioning of the 3 mesocosms following 2dimensional clustering of experimental biological and chemical parameters, as discussed by Passow et al. (2007). The effect of phytoplankton (in the balanced or net autotrophic mesocosms) could also explain the differences seen in bacterial community succession between the phytoplankton addition mesocosms versus the No Addition tank. The Phaeocystis and Diatom tank communities varied in a non-linear fashion in comparison to the NA community, which shifted progressively away from initial composition (Fig. 4A) and clustered separately over the last 8 to $10 \mathrm{~d}$ (Fig. 3). This change corresponds to the nutrient and carbon (i.e. drawdown of organic phosphorus, organic carbon, and total dissolved carbohydrates) and biological (algal and heterotrophic grazer) dynamics that were more variable in the phytoplankton addition mesocosms (Grosshart et al. 2007, Passow et al. 2007). This pattern contrasts with the hydrolysis rate determinations, in which the similarities among the experimental treatments were stronger than the differences between them.

If the phytoplankton blooms had exhausted nutrient supplies (as began to occur in the Diatom tank on the last 2 d), a change in phytoplankton exudates might have catalyzed differences in enzymatic dynamics among the mesocosms. Measurements assessing potential aminopeptidase activity, however, did reflect the differences in mesocosm trophic status to a greater degree after Day 10 of the experiment, when the phytoplankton addition mesocosms had increased activity levels compared to the No Addition tank. Interestingly, though the aminopeptidase activities were similar in both the Phaeocystis and Diatom tanks, the substrates being hydrolyzed in the Phaeocystis tank came from the senescence of the bloom, whereas they came from growing phytoplankton in the Diatom tank (Grosshart et al. 2007). Changes in bacterial community structure in response to phytoplankton additions (Riemann et al. 2000, Pinhassi et al. 2004) or in response time to different phytoplankton additions (Sanders \& Purdie 1998) have been observed in other studies. 


\section{Temporal changes in microbial community composition}

Despite initial non-congruent shifts in community composition of the 3 mesocosms over the first $18 \mathrm{~h}$ of the experiment, the most dominant changes in bacterial communities in all mesocosms were concurrent shifts in community structure during Days 8 to 10 (Figs. 2, 3 \& 4A) and in microbial activity during Days 11 to 13 (Fig. 4B). This timing coincided with development of nanoflagellate grazers in all 3 mesocosms and preceded the major growth period in the Diatom tank. In other studies, bacterial community structure was shown to be influenced both by confinement in a No Addition experiment and by grazer-induced mortality (Schäfer et al. 2000) and in a study investigating the influence of light on bacterioplankton (Schwalbach et al. 2005), both of which appear to be similar to what we observed at least for the first half of the experiment.

Temporally varying chemistry of the mesocosm system yielded clues to ecological relationships between the bacteria and their resources. For example, DFCHO, which accumulated over the course of the experiment, correlated with several phylotypes. In addition, organic phosphorus measurements (DOP, $\mathrm{POP}), \mathrm{PO}_{4}$, and total $\mathrm{P}$ covaried with phylotypes identified (Table 2). Passow et al. (2007) concluded that the bacterial community utilized organic phosphorus (there was almost no utilization of $\mathrm{PO}_{4}$ in the No Addition tank). Although we are not aware of instances in which inorganic phosphorus has been reported as a sole controlling factor influencing bacterial community structure, inorganic nutrient addition experiments (combining nitrate, phosphate, and ammonium) have been shown to affect bacterial community structure (Schäfer et al. 2001), although not to the extent observed when carbon substrates are supplemented with inorganic nutrients (Carlson et al. 2002, Ovreas et al. 2003). Correlations of individual phylotypes with different forms of phosphate suggest that in a system not limited by carbon, these phylotypes may have utilized different P-sources over the experimental period as availability and competition changed.

Glaciecola-related NA6-2, which was detected throughout the experiment in all mesocosms, had a signal 3 times higher over the first half of the experiment and correlated with DOP, nitrate, phosphate, and xylan hydrolysis. The Glaciecola genus is not particularly well known, except for 2 species (Bowman et al. 1998), which were reported to have starch, $\alpha$-galactosidase, and $\beta$-galactosidase hydrolytic activities, as well as alkaline phosphatase activity. In contrast, several rather dominant Gammaproteobacteria phylotypes (e.g. NA1-3 and D14-1) seemed to be favored in the later part of the experiment, particularly in the phyto- plankton addition mesocosms. Relatives of these phylotypes and NA12-3 are members of the Oligotrophic Marine Group (Cho \& Giovannoni 2004), a newly recognized group of potentially important marine oligoheterotrophic bacteria. This group is thought to thrive in low-nutrient conditions; however, in our case, levels of most macronutrients were relatively high, with phosphorus suspected to be the most limiting macronutrient (Passow et al. 2007), and, though DOC concentrations dropped throughout the experiment, final

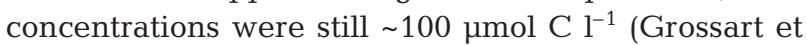
al. 2007).

Both natural marine systems and manipulated mesocosm studies have described phytoplankton-bacterioplankton associations (Pinhassi \& Hagström 2000, Hold et al. 2001, Zubkov et al. 2001, Grossart et al. 2005) or bacteria that are affiliated with phytoplankton-derived detritus (Van Hannen et al. 1999, Bidle \& Azam 2001). Here, we detected a Sulfitobacter-related phylotype, P14-3, along with P14-2 affiliated with the Gammaproteobacteria in the phytoplankton addition mesocosms. Members of the Roseobacter-Sulfitobacter-Silicibacter clade have, in several instances, been reported to be affiliated specifically with marine algae (e.g. Riemann et al. 2000). Another Sulfitobacter-related phylotype, D18-3, was detected after Day 10 in all 3 mesocosms, which is not likely to be the result of a phytoplankton-bacterioplankton association (the No Addition tank had negligible phytoplankton growth). This phylotype signal did correlate positively with DFCHO, DFrhamnose, and small heterotrophic nanoflagellates, and negatively with $\mathrm{NO}_{3}{ }^{-}, \mathrm{PO}_{4}, \mathrm{DOP}$, and total $\mathrm{P}$, which were being drawn down during this time.

\section{Correlation between community composition and hydrolytic activity}

Although a large number of investigations have studied the hydrolytic capabilities of marine microbial communities (e.g. Riemann et al. 2000, Kirchman et al. 2004, Pinhassi et al. 2004) and isolated bacteria (e.g. Martinez et al. 1996, Alderkamp et al. 2007), knowledge of links between individual members of complex communities and hydrolysis of specific highmolecular-weight substrates-rather than substrate proxies - is still extremely sparse. In one study using substrate proxies, Kirchman et al. (2004) found that community structure (represented as groups of Alpha-, Beta- and Gammaproteobacteria, and Cytophaga) explained much of the variance in ectoenzyme activity observed. The results presented here take these studies one step further by establishing links between hydrolysis of specific polysaccharides and specific microbial phylotypes in a complex community. 
Temporal changes in hydrolysis patterns of specific polysaccharides were quite large; these changes were remarkably concordant among all 3 mesocosms, despite differences in their plankton communities. This concordance suggests that specific enzyme activities were under the control of distinct member(s) of the microbial community and/or their predators, and were affected to a lesser extent by the presence or nature of the algal community. MDS (Fig. 4B) showed that (1) there was a difference between the activities measured (polysaccharide hydrolysis and aminopeptidase) over the first $11 \mathrm{~d}$ and the last $7 \mathrm{~d}$ of the experiment and (2) the activities detected in the Diatom tank on Days 15 and 19 were distinct from all the other samples. Furthermore, individual hydrolytic activities correlated with specific biological and chemical features of the mesocosms (Appendix 1).

The shifts in community structure around Days 11 to 13 coincided with a very large decline in xylan hydrolysis and an increase in chondroitin hydrolysis, while Isochrysis extract hydrolysis continued to decline. At this time, phylotype NA6-2 (related to the Glaciecola sp. clone) decreased significantly in intensity (discussed above), and phylotypes P8-3 and P6-4 (related to 2 alphaproteobacterium clones) dropped below detection levels. NA6-2 and P8-3 correlated significantly with xylan hydrolysis, and P6-4 with Isochrysis DOC hydrolysis. Conversely, phylotype NA18-3, distantly related (89\% sequence identity) to Deltaproteobacteria and Verrucomicrobia phylotypes, was detected and correlated significantly with the chondroitin hydrolysis rate. The patterns of the 2 alphaproteobacterium phylotypes correlated negatively with small heterotrophic grazers, suggesting that they were potentially grazed from the system. Thus, the reduction in xylan hydrolysis activity could have been the result of specific grazing of organisms capable of hydrolyzing xylan.

Changes in community composition may also occur at maxima in enzyme activities measured by small substrate proxies (Fandino et al. 2001), although those studies did not link activities to specific organisms and did not probe specific polysaccharide hydrolase activities. The results here suggest phylotype-activity correlations that could be tested in the future using cultivated isolates of the organisms identified here. Our understanding of hydrolytic capabilities has also been enhanced through genome sequencing. For example, a comparison between 16 marine alpha- and gammaproteobacterial genomes plus a Cytophaga genome (Appendix 2, available as Supplementary Material online at www.int-res.com/journals/suppl/a049p123_app.pdf), using the comparative annotation features of Integrated Microbial Genomes (Markowitz et al. 2006), suggests that several Gammaproteobacteria are capable of xylan hydrolysis (to the exclusion of the other genomes sur- veyed) - which is consistent with the finding here that the Glaciecola-related phylotype correlated with xylan hydrolytic activity.

Leu-MCA activity, which reached the highest rates observed on Days 18 and 20 in the Diatom tank, correlated positively with phylotype NA18-3 (as did chondroitin hydrolysis), at the same time when the diatom bloom peaked and the Phaeocystis tank was in a relatively balanced growth state. The specificity of enzymes capable of hydrolyzing the Leu-MCA bond has not been well characterized, and likely extends beyond just leucyl-aminopeptidase activity. As the genome comparisons show (Appendix 2), aminopeptidases are common features of marine bacterial genomes: 12 of 17 genomes surveyed encoded this enzyme. Other mesocosm studies (Riemann et al. 2000, Pinhassi et al. 2004) have shown increases in aminopeptidase activity as measured by Leu-MCA, which closely reflected phytoplankton growth in the mesocosm experiments. Though the intent in our investigation was to measure bacterial amino acid utilization, it is possible that the increases seen in the Phaeocystis and Diatom tanks were due, in part, to algal aminopeptidase activity. Although rarely studied, algal peptide hydrolysis has been demonstrated in the pelagophyte Aureococcus anophagefferens (Mulholland et al. 2002). In addition, the Thalassiosira pseudonana genome encodes several homologs of leucine aminopeptidase (Armbrust et al. 2004), supporting the notion that various algal species may be capable of peptide hydrolysis. The changes observed in patterns of hydrolysis coinciding with changes in bacterial communities point to the importance of specific phylotypes in relation to specific enzyme activities, which has been noted by others (Martinez et al. 1996, Fandino et al. 2001). Further, some linkages were undoubtedly missed, as this study focused analysis on the community structure of the freeliving bacterioplankton community, even though some of the hydrolytic enzyme activities determined could have been derived from the attached community as Riemann et al. (2000) have reported. The significant contribution of dissolved free enzymes to laminarin and chondroitin hydrolysis, however, suggests that enzymes released from bacteria (whether through active release or as a result of viral lysis or grazing) can also contribute substantially to hydrolytic activities.

\section{Utilization of different polysaccharides by microbial communities}

A comparison of the polysaccharide hydrolase activities measured during the course of this experiment highlights the complexity of microbial responses to high-molecular-weight substrates. These data include, 
for the first time, enzymatic hydrolysis rates of DOC derived from phytoplankton and the Skeletonemaderived substrate. In comparison to the purified polysaccharides, the Skeletonema-derived substrate and Isochrysis extract are both a step closer to the complex heterogeneous organic matter naturally available as substrates to marine microbial communities. Such data have not previously been obtained, since other investigations of the activity of carbohydrate-hydrolyzing enzymes during natural and induced phytoplankton blooms (e.g. Pinhassi et al. 1999, Riemann et al. 2000) have used small substrate proxies (e.g. MUF $\alpha$ - and $\beta$ glucose) rather than polysaccharides to estimate enzyme activities; the relationship between rates measured with such proxies and hydrolysis rates of the macromolecules they are intended to represent is uncertain (Warren 1996).

Some polysaccharides with similar bulk compositional characteristics (soluble linear glucose polysaccharides: pullulan, laminarin) and roles (storage polysaccharides: laminarin, Isochrysis extract) were hydrolyzed at very different rates. Low hydrolysis rates of pullulan contrasted with relatively rapid hydrolysis of laminarin (Fig. 5). These substrates differ solely in the linkage position and orientation of their glucose chains: $\alpha(1,4)$ and $\alpha(1,6)$ linkages for pullulan and $\beta(1,3)$ linkages for laminarin. The comparatively low hydrolysis rate of the Isochrysis extract was also surprising, since the Isochrysis extract (like laminarin) is likely a phytoplankton energy-storage product. It constitutes a large fraction of the original plankton biomass $(13 \%$ of cell mass) and is predominantly (65\%) composed of glucose, with lesser contributions of arabinose, galactose, mannose, and xylose $(7,5,4$, and $2 \%$, respectively; Arnosti et al. 2005b). The composition and the linkage analysis (showing 1,3-linked components with branch points; C. Arnosti unpubl. data) suggest that the extract could be chrysolaminarin, an energy-storage product of haptophytes (Raven 2005), which is structurally similar to the laminarin found in diatoms.

Complexity or heterogeneity of structure, however, is not a direct indication of bioavailability, as shown by the relatively rapid hydrolysis of the Skeletonemaderived DOC and the lack of hydrolysis of fucoidan. High-molecular-weight Skeletonema-derived DOC contains a heterogeneous mix of carbohydrate constituents: Biersmith \& Benner (1998) found that the high-molecular-weight fraction (>1000 Da) DOC of a Skeletonema culture was $74 \%$ carbohydrate, approximately half of which could be identified as neutral aldoses (predominantly glucose, some mannose and fucose, and smaller amounts of ribose, rhamnose, galactose, xylose, with traces of lyxose and arabinose). Fucoidan, a sulfated fucose-containing marine polysaccharide, was not hydrolyzed in any mesocosm, despite the fact that its source organism (algae of the genus Fucus) is common in the marine environment.

The extent to which dissolved enzymes contributed to hydrolysis also varied among substrates, and was considerable for specific substrates and time points (Fig. 6). The extent to which enzymes in general are freely released into solution by microbial communities is not precisely known. A previous investigation in the Delaware River and Bay showed that the contribution of dissolved laminarinase and xylanase enzymes to total enzyme activities could be quite high (up to $100 \%$ of total activity), but varied by season, site, and substrate (Keith \& Arnosti 2001). Release of enzymes, including laminarinase, has been observed in cultured isolates (Alderkamp et al. 2007), and has been linked to the microbial growth phase (Antranikian et al. 1987) or could be a response to starvation (Albertson et al. 1990), a result of viral lysis (Karner \& Rassoulzadegan 1995), or a result of grazing (Bochdansky et al. 1995). Since the ultimate source of these enzymes is the bacterial community, differences between the tanks in the extent to which activity was attributable to free enzymes (e.g. laminarin) may thus be related to slight 'phase shifts' between the tanks, i.e. slight differences in growth phase, susceptibility to grazers, or viruses. The relative uniformity of patterns across mesocosms and substrates - moderate to substantial contributions of free laminarinase enzymes, substantial contribution of chondroitin hydrolase enzymes, and a lack of contribution of free xylanase enzymes - suggests that in the mesocosm, the extent to which activity is associated with a cell is not random but is under specific control, either of the bacteria, or of their predators. Since the active lifetime of an enzyme released into solution is unknown, the dissolved enzyme activity could be due to specific events releasing enzymes that then persisted in solution, retaining their activity over time, or it could reflect continual production of dissolved enzymes, balanced by deactivation.

\section{SUMMARY}

In these mesocosms, bacterial community structure, to a greater extent than enzymatic potential of the community, was influenced by the nature and development of the primary producer community. Despite the effect of the primary producers on the mesocosm food web biology and chemistry (Grosshart et al. 2007, Passow et al. 2007, present study), all 3 mesocosms exhibited a significant concordant shift in bacterial community structure and hydrolytic potential midway through the experiment that was coincident with depletion of initial carbon resources (Grosshart et al. 2007) and grazer control (Passow et al. 2007) of the experimental systems. 
Acknowledgements. We are grateful for the help of S. Schlake in sample processing, and R. Cooper in the molecular biological research. This work was supported, in part, by the NSF (Grants: OCE-0323975, OCE-9906089, and INT-9813991 to C.A. and OPP-0085435 to A.E.M.), by the Petroleum Research Fund (C.A.), and the Desert Research Institute. C.A. was supported as a fellow at the Hanse-Wissenschaftskolleg (Delmenhorst), during this experiment.

\section{LITERATURE CITED}

Albertson NH, Nystrom T, Kjelleberg S (1990) Macromolecular-synthesis during recovery of the marine Vibrio sp. S14 from starvation. J Gen Microbiol 136:2201-2207

Alderkamp AC, van Rijssel M, Bolhuis H (2007) Characterization of marine bacteria and the activity of their enzyme systems involved in degradation of the algal storage glucan laminarin. FEMS Microbiol Ecol 59:108-117

Altschul SF, Gish W, Miller W, Myers EW, Lipman DJ (1990) Basic local alignment search tool. J Mol Biol 215:403-410

Amon RMW, Benner R (1994) Rapid cycling of high-molecular weight dissolved organic matter in the ocean. Nature 369: 549-552

Antranikian G, Herzberg C, Gottschalk G (1987) Production of thermostable $\alpha$-amylase, pullulanase, and $\alpha$-glucosidase in continuous culture by a new isolate. Appl Environ Microbiol 53:1668-1673

Armbrust EV, Berges JA, Bowler C, Green BR and others (2004) The genome of the diatom Thalassiosira pseudonana: ecology, evolution, and metabolism. Science 306: 79-86

Arnosti C (1995) Measurement of depth-related and siterelated differences in polysaccharide hydrolysis rates in marine-sediments. Geochim Cosmochim Acta 59: $4247-4257$

Arnosti C (2000) Substrate specificity in polysaccharide hydrolysis: contrasts between bottom water and sediments. Limnol Oceanogr 45:1112-1119

Arnosti C (2003) Fluorescent derivatization of polysaccharides and carbohydrate-containing biopolymers for measurement of enzyme activities in complex media. J Chromatogr B 793:181-191

Arnosti C, Durkin S, Jeffrey WH (2005a) Patterns of extracellular enzyme activities among pelagic marine microbial communities: implications for cycling of dissolved organic carbon. Aquat Microb Ecol 38:135-145

Arnosti C, Finke N, Larsen O, Ghobrial S (2005b) Anoxic carbon degradation in Arctic sediments: microbial transformations of complex substrates. Geochim Cosmochim Acta 69:2309-2320

Arrieta JM, Weinbauer MG, Lute C, Herndl GJ (2004) Response of bacterioplankton to iron fertilization in the Southern Ocean. Limnol Oceanogr 49:799-808

Bidle KD, Azam F (2001) Bacterial control of silicon regeneration from diatom detritus: significance of bacterial ectohydrolases and species identity. Limnol Oceanogr 46: 1606-1623

Biersmith A, Benner R (1998) Carbohydrates in phytoplankton and freshly produced dissolved organic matter. Mar Chem 63:133-144

Bochdansky AB, Puskaric S, Herndl GJ (1995) Influence of zooplankton grazing on free dissolved enzymes in the sea. Mar Ecol Prog Ser 121:53-63

Bowman JP, McCammon SA, Brown JL, McMeekin TA (1998) Glaciecola punicea gen. nov., sp. nov. and Glaciecola pallidula gen. nov., sp. nov.: psychrophilic bacteria from Antarctic sea-ice habitats. Int J Syst Bacteriol 48: 1213-1222

Carlson CA, Giovannoni SJ, Hansell DA, Goldberg SJ, Parsons R, Otero MP, Vergin K, Wheeler BR (2002) Effect of nutrient amendments on bacterioplankton production, community structure and DOC utilization in the northwestern Sargasso Sea. Aquat Microb Ecol 30:19-36

Cho JC, Giovannoni SJ (2004) Cultivation and growth characteristics of a diverse group of oligotrophic marine Gammaproteobacteria. Appl Environ Microbiol 70: 432-440

Cottrell MT, Kirchman DL (2000) Natural assemblages of marine proteobacteria and members of the CytophagaFlavobacter cluster consuming low- and high-molecularweight dissolved organic matter. Appl Environ Microbiol 66:1692-1697

DeLong EF, Preston CM, Mincer T, Rich V and others (2006) Community genomics among stratified microbial assemblages in the ocean's interior. Science 311:496-503

Eisen MB, Spellman PT, Brown PO, Botstein D (1998) Cluster analysis and display of genome-wide expression patterns. Proc Natl Acad Sci USA 25:14863-14868

Falkowski PG, Barber RT, Smetacek V (1998) Biogeochemical controls and feedbacks on ocean primary production. Science 281:200-206

Fandino LB, Riemann L, Steward GF, Long RA, Azam F (2001) Variations in the bacterial community structure during a dinoflagellate bloom analyzed by DGGE and 16S rDNA sequencing. Aquat Microb Ecol 23:119-130

Fromin N, Hamelin J, Tarnawski S, Roesti D and 6 others (2002) Statistical analysis of denaturing gel electrophoresis (DGE) fingerprinting patterns. Environ Microbiol 4: $634-643$

Fuhrman JA, Azam F (1982) Thymidine incorporation as a measure of heterotrophic bacterioplankton production in marine surface waters: evaluation and field results. Mar Biol 66:109-120

Giovannoni S, Rappe M (2000) Evolution, diversity, and molecular ecology of marine prokaryotes. In: Kirchman DL (ed) Microbial ecology of the oceans. Wiley-Liss, New York, p 47-84

Glabe CG, Harty PK, Rosen SD (1983) Preparation and properties of fluorescent polysaccharides. Anal Biochem 130: $287-294$

Grossart HP, Levold F, Allgaier M, Simon M, Brinkhoff T (2005) Marine diatom species harbour distinct bacterial communities. Environ Microbiol 7:860-873

Grossart HP, Engel A, Arnosti C, De La Rocha CL, Murray AE, Passow U (2007) Microbial dynamics in autotrophic and heterotrophic seawater mesocosms. III. Organic matter fluxes. Aquat Microb Ecol 49:143-156

Hewson I, Jacobson-Meyers ME, Fuhrman JA (2007) Diversity and biogeography of bacterial assemblages in surface sediments across the San Pedro Basin, Southern California borderlands. Environ Microbiol 9:923-933

Hold GL, Smith EA, Rappe MS, Maas EW and 6 others (2001) Characterisation of bacterial communities associated with toxic and non-toxic dinoflagellates: Alexandrium spp. and Scrippsiella trochoidea. FEMS Microbiol Ecol 37:161-173

Hoppe HG, Kim SJ, Gocke K (1988) Microbial decomposition in aquatic environments: combined process of extracellular enzyme activity and substrate uptake. Appl Environ Microbiol 54:784-790

Kan J, Wang K, Chen F (2006) Temporal variation and detection limit of an estuarine bacterioplankton community analyzed by denaturing gradient gel electrophoresis (DGGE). Aquat Microb Ecol 42:7-18 
Karner M, Rassoulzadegan F (1995) Extracellular enzymeactivity - indications for high short-term variability in a coastal marine ecosystem. Microb Ecol 30:143-156

Keith S, Arnosti C (2001) Extracellular enzyme activity in a river-bay-shelf transect: variations in polysaccharide hydrolysis rates with substrate and size class. Aquat Microb Ecol 24:243-253

Kirchman D, K'Nees E, Hodson R (1985) Leucine incorporation and its potential as a measure of protein synthesis by bacteria in natural aquatic systems. Appl Environ Microbiol 49:599-607

Kirchman DL, Dittel AI, Findlay SEG, Fischer D (2004) Changes in bacterial activity and community structure in response to dissolved organic matter in the Hudson River, New York. Aquat Microb Ecol 35:243-257

Kruskal JB (1964) Nonmetric multidimensional scaling: a numerical method. Pyrometrical 29:1-27

Kruskal JB, Wish M (1978) Multidimensional scaling. Sage Publications, Beverly Hills, CA

Magurran AE (1988) Ecological diversity and its measurement. Princeton University Press, Princeton, NJ

Markowitz VM, Korzeniewski F, Palaniappan K, Szeto E and 10 others (2006) The integrated microbial genomes system. Nucleic Acids Res 34:344-348

Martin DL, Ross RM, Quetin LB, Murray AE (2006) Molecular approach (PCR-DGGE) to diet analysis in young Antarctic krill Euphasia superba. Mar Ecol Prog Ser 319:155-165

Martinez J, Smith DC, Steward GF, Azam F (1996) Variability in ectohydrolytic enzyme activities of pelagic marine bacteria and its significance for substrate processing in the sea. Aquat Microb Ecol 10:223-230

Massana R, Murray AE, Preston CM, DeLong EF (1997) Vertical distribution and phylogenetic characterization of marine planktonic Archaea in the Santa Barbara Channel. Appl Environ Microbiol 63:50-56

McCarthy M, Hedges J, Benner R (1996) Major biochemical composition of dissolved high molecular weight organic matter in seawater. Mar Chem 55:281-297

Moran MA, Buchan A, Gonzalez JM, Heidelberg JF and others (2004) Genome sequence of Silicibacter pomeroyi reveals adaptations to the marine environment. Nature 432:910-913

Mulholland MR, Gobler CJ, Lee C (2002) Peptide hydrolysis, amino acid oxidation, and nitrogen uptake in communities seasonally dominated by Aureococcus anophagefferens. Limnol Oceanogr 47:1094-1108

Murray AE, Hollibaugh JT, Orrego C (1996) Phylogenetic compositions of bacterioplankton from two California estuaries compared by denaturing gradient gel electrophoresis of 16S rDNA fragments. Appl Environ Microbiol 62:2676-2680

Murray AE, Preston CM, Massana R, Taylor LT, Blakis A, Wu K, DeLong EF (1998) Seasonal and spatial variability of bacterial and archaeal assemblages in the coastal waters off Anvers Island, Antarctica. Appl Environ Microbiol 64: 2585-2595

Osborn AM, Moore ERB, Timmis KN (2000) An evaluation of terminal-restriction fragment length polymorphism (T-RFLP) analysis for the study of microbial community structure and dynamics. Environ Microbiol 2:39-50

Øvreås L, Bourne D, Sandaa RA, Casamayor EO and 5 others (2003) Response of bacterial and viral communities to nutrient manipulations in seawater mesocosms. Aquat Microb Ecol 31:109-121

Passow U, De La Rocha CL, Arnosti C, Grossart HP, Murray AE, Engel A (2007) Microbial dynamics in autotrophic and heterotrophic seawater mesocosms. I. Effect of phytoplankton on the microbial loop. Aquat Microb Ecol 49:109-121

Pinhassi J, Hagström Å (2000) Seasonal succession in marine bacterioplankton. Aquat Microb Ecol 21:245-256

Pinhassi J, Azam F, Hemphälä J, Long RA, Martinez J, Zweifel UL, Hagström A (1999) Coupling between bacterioplankton species composition, population dynamics, and organic matter degradation. Aquat Microb Ecol 17: $13-26$

Pinhassi J, Sala MM, Havskum H, Peters F, Guadayol O, Malits A, Marrase CL (2004) Changes in bacterioplankton composition under different phytoplankton regimes. Appl Environ Microbiol 70:6753-6766

Raven JA (2005) Cellular location of starch synthesis and evolutionary origin of starch genes. J Phycol 41: 1070-1072

Riemann L, Steward GF, Azam F (2000) Dynamics of bacterial community composition and activity during a mesocosm diatom bloom. Appl Environ Microbiol 66:578-587

Sanders R, Purdie DA (1998) Bacterial response to blooms dominated by diatoms and Emiliania huxleyi in nutrientenriched mesocosms. Estuar Coast Shelf Sci 46:35-48

Schäfer H, Müyzer G (2001) Denaturing gradient gel electrophorsis in marine microbial ecology. In: Paul JH (ed) Marine microbiology, methods in microbiology. Academic Press, San Diego, CA, p 425-468

Schäfer H, Servais P, Müyzer G (2000) Successional changes in the genetic diversity of a marine bacterial assemblage during confinement. Arch Microbiol 173:138-145

Schäfer $\mathrm{H}$, Bernard L, Courties C, Lebaron P and 7 others (2001) Microbial community dynamics in Mediterranean nutrient-enriched seawater mesocosms: changes in the genetic diversity of bacterial populations. FEMS Microbiol Ecol 34:243-253

Schwalbach MS, Brown M, Fuhrman JA (2005) Impact of light on marine bacterioplankton community structure. Aquat Microb Ecol 39:235-245

Šimek K, Hartman P, Nedoma J, Pernthaler J, Springmann D, Vrba J, Psenner R (1997) Community structure, picoplankton grazing and zooplankton control of heterotrophic nanoflagellates in a eutrophic reservoir during the summer phytoplankton maximum. Aquat Microb Ecol 12:49-63

Sturrock K, Rocha J (2000) A multidimensional scaling stress evaluation table. Field Methods 12:49-60

Suzuki MT, Giovannoni SJ (1996) Bias caused by template annealing in the amplification of mixtures of $16 \mathrm{~S}$ rRNA genes by PCR. Appl Environ Microbiol 62:625-630

Thompson J, Rando MA, Marcelino LA, Tomita-Mitchell A, Lim E, Polz MF (2004) Diversity and dynamics of a North Atlantic coastal Vibrio community. Appl Environ Microbiol 70:4103-4110

Van Hannen EJ, Mooij W, Agterveld MPv, Gons HJ, Laanbroek HJ (1999) Detritus-dependent development of the microbial community in an experimental system: qualitative analysis by denaturing gradient gel electrophoresis. Appl Environ Microbiol 65:2478-2484

Warren RAJ (1996) Microbial hydrolysis of polysaccharides. Ann Rev Microbiol 50:183-212

Wommack KE, Colwell RR (2000) Virioplankton: viruses in aquatic ecosystems. Microbiol Mol Biol Rev 64:69-114

Zubkov MV, Fuchs BM, Archer SD, Kiene RP, Amann R, Burkill PH (2001) Linking the composition of bacterioplankton to rapid turnover of dissolved dimethylsulphoniopropionate in an algal bloom in the North Sea. Environ Microbiol 3:304-311 